\title{
GROUND-WATER RESOURCES AND GEOLOGY OF COOK COUNTY, GEORGIA
}

By

Charles w. Sever, / 931 
s)

imctoüusion

Pupax and scope of the investigation

ITevarus irvestigrtions

Mentrois of imustigntion

Well muminet.

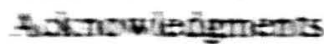

पym-pwaing standards

ITrI.

Sulize

Chistine

Winge

Furrine

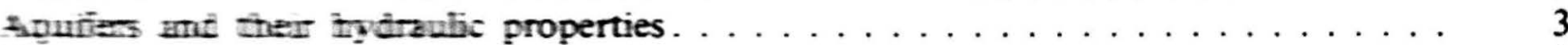

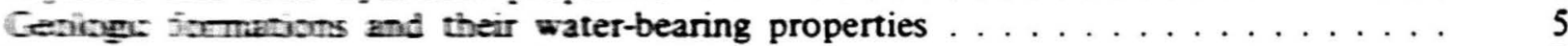

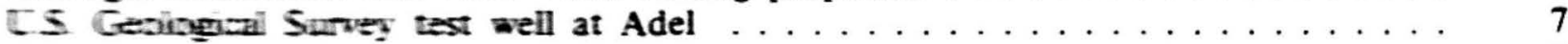

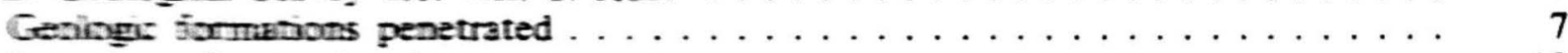

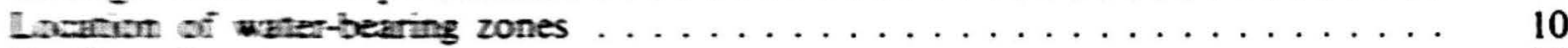

Quabir of wher . . . . . . . . . . . . . . . . . 12

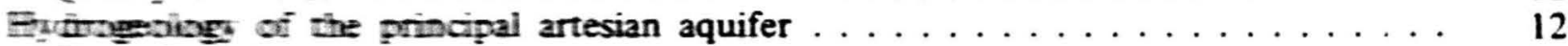

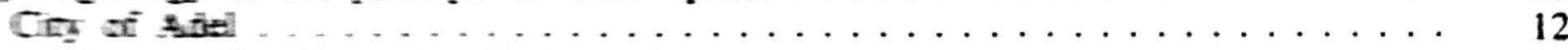

Eissurg of well constraction .................... 12

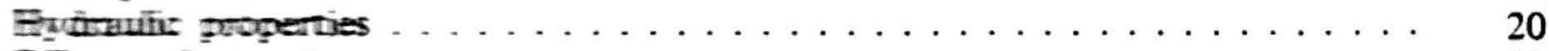

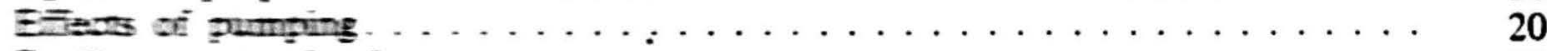

Decimme wrter levels . . . . . . . . . . . . . . 20

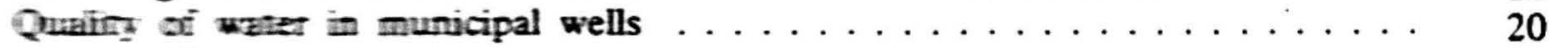

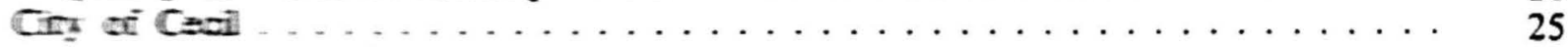

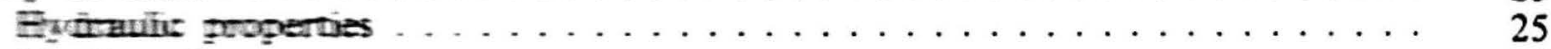

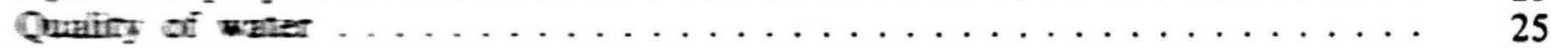

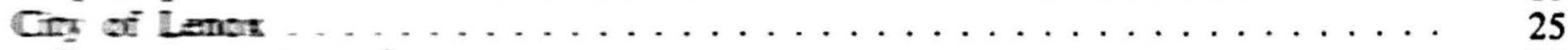

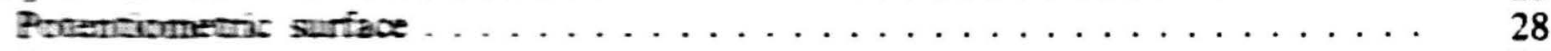

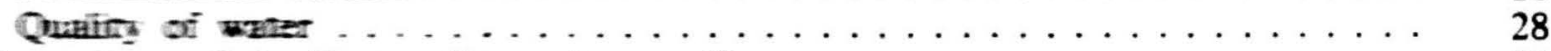

Eutropesiogs of the Tampa Formation aquifer . . . . . . . . . . . . 29

CS Geciogncal Survey test well at Laconte . . . . . . . . . . . . . . . 29

Eycuraitic properties of the Tampa Formation . . . . . . . . . . . . 29

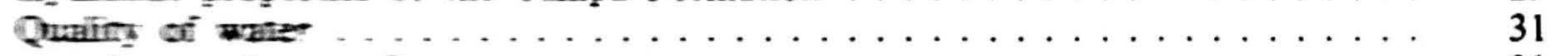

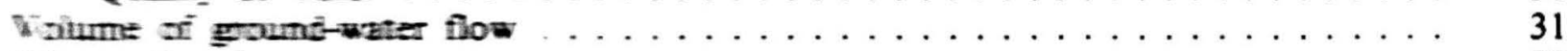

orne mineri resouros . . . . . . . . . . . . . . . . . . 39

Surnmara and condusions. . . . . . . . . . . . . . . 40

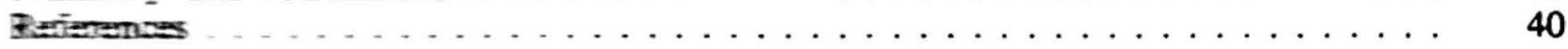




\section{ILLUSTRATIONS}

TABLES

Page

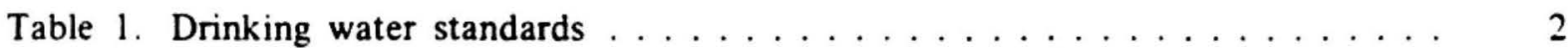

2. Location and yield of water-bearing zones at Adel, Ga.. . . . . . . . . 11

3. Construction data for municipal wells at Adel, Ga. . . . . . . . . . 13

4. Chemical analyses of water from wells in Cook County, Ga. . . . . . . . 22

5. Record of well . . . . . . . . . . . . . . . . . . 32

6. Sieve analyses of sand from flood plain of Little River, western Cook

County, Ga.

\section{FIGURES}

Figure 1. Map showing locations of wells and configuration of potentiometric surface in the principal artesian aquifer, April 1966

2. Geologic map and configuration of the top of Suwannee Limestone. . . 6

3. Map of Adel showing locations of wells . . . . . . . . . . . 8

4. Geophysical logs and distribution of water-bearing zones at Adel

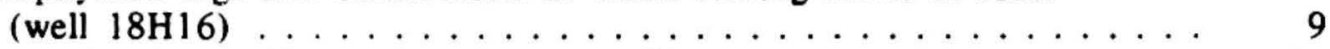

5. Data plot for aquifer test of Suwannee Limestone at Adel . . . . . . . . 21

6. Graph showing theoretical drawdown at Adel after 10 years continuous

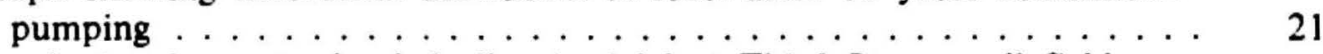

7. Graph showing water-level decline in Adel at Third Street well field,

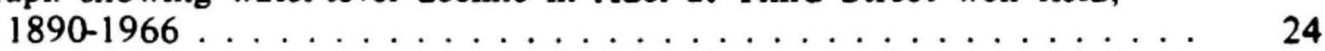

8. Hydrographs of water levels in three Cock County wells during 1965-66. 26

9. Map of Cecil showing location of well .............. 26

10. Geophysical logs of well at Cecil $(18 \mathrm{G} 18) \ldots \ldots \ldots \ldots$

11. Data plot for aquifer test of Suwannee Limestone at Cecil . . . . . . . . 27

12. Map showing configuration of the top of the Tampa Fo'mation and location of low grade phosphate deposits ........... 30

13. Data plot for aquifer test in Tampa Formation at Laconte . . . . . . . . 38 


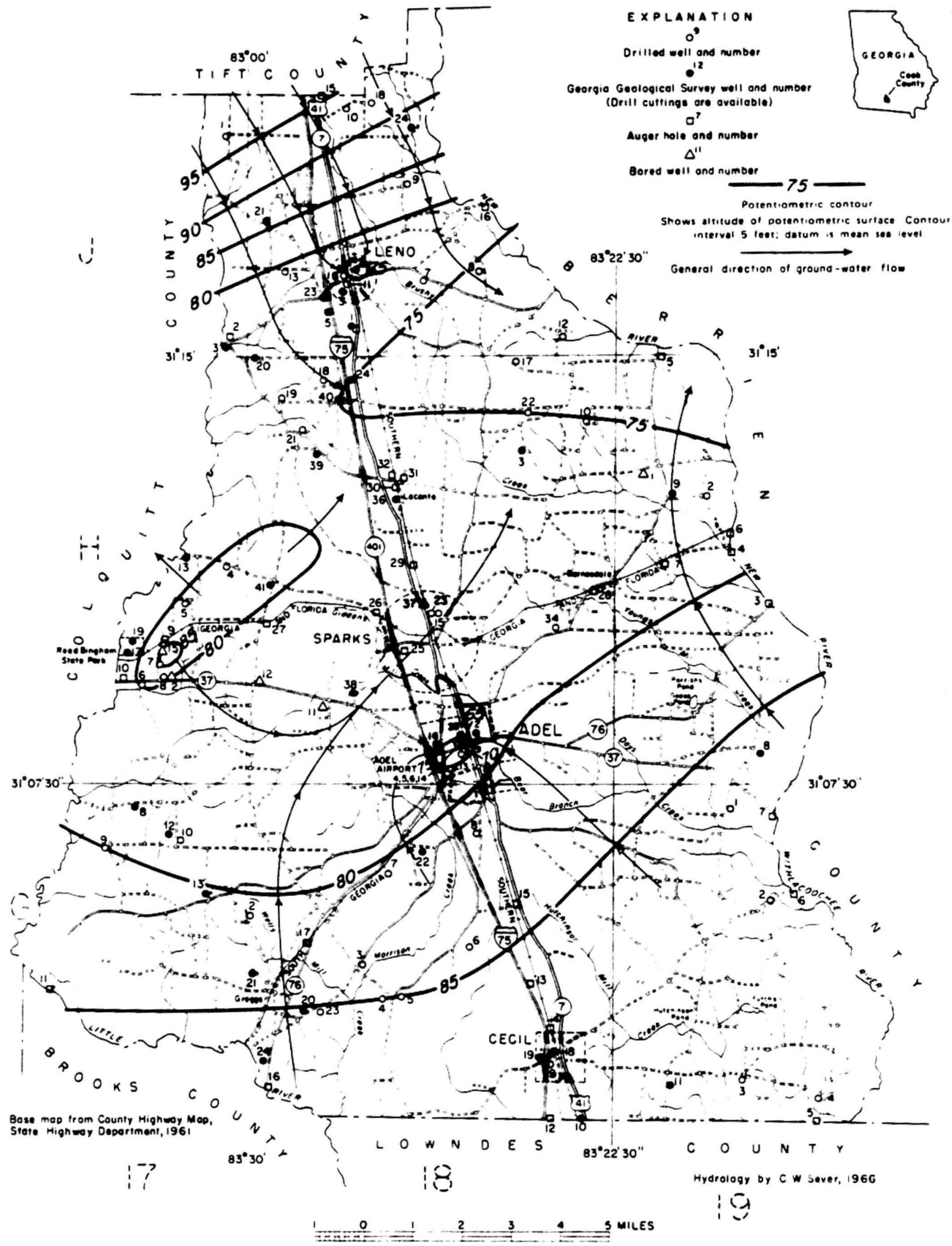

Figure 1. - Map showing locations of wells and potentiometric surface in the principal artesian aquifer, April 1966. 


\title{
GROUND-WATER RESOURCES AND GEOLOGY \\ OF COOK COUNTY, GEORGIA
}

\author{
Charles W. Sever
}

\begin{abstract}
Aquifer-performance tests and aquifer studies indicate that the limestone beneath the city of Adel and probably me $t$ of Cook County contains potable water to a depth of only about 400 to 500 feet and that "deep" wells that tap these limestones obtain most of their water from a few thin, highly permeable zones rather than from the entire thickness of the rocks. Below about 500 feet the water is mineralized and not potable without treatment. The yield of "shallow wells" is variable and the water generally is corrosive and at places contains appreciable dissolved iron.

The volume of ground water flowing through the Suwannee and Marianna Limestones in Cook County and available for development to properly spaced wells and well fields is estimated to be about 18,000,000 gallons per day. That in the Tampa Formation is estimated to be about $1,500,000$ gallons per day

Water levels near the center of the Adel well field have declined 38 feet since 1890 and presently are declining at a rate of 1.6 feet per year.
\end{abstract}

\section{INTRODUCTION}

\section{Purpose and Scope of the Investigation}

A ground-water investigation at Adel and in Cook County was made for the purpose of evaluating the quantity and quality of grounc water available for industrial and municipal use and to provide information about the water-bearing zones in the limestones which will allow the orderly development of this resource.

Ground water is the principal source of water supply for Cook County and the city of Adel. Adel, the county seat of Cook County, is located in the central part of southern Georgia. (See index map, fig. 1) The county is in the Atlantic Coastal Plain physiographic province. Previous limited knowledge indicated that the limestones tapped by water wells in Cook County might have several water-bearing zones that contain water of different quality. For example, large quantities of dissolved sulfate are present in some but not all municipal and irrigation wells. Also, a few wells yield smali quantities of silt and fine sand suspended in the water, while most wells never produce silt or sand.

\section{Previous Investigations}

General geological and ground-water information about the area is included in McCallie (1898), Cooke (1943), Stephenson and Veatch (1915), and Herrick and Vorhis (1963). Herrick $(1961$, p. 134 to 137) has published detailed lithologic and paleontological logs of four wells in Cook County, two of which are in Adel. Wait (1960, p. 43) gave a chemical analysis of water collected from a well in Adel, and McCallie (1908, p. 52) published a record made by Mr. J. B. Spencer of the material penetrated by a well. Published geologic maps by both Cooke (1943) and MacNeil (1947) include Cook County.

\section{Methods of Investigation}

Hydrologic data were obtained by inventorying water wells over the county and conducting aquifer-performance tests at municipal well fields and at Reed Bingham State Park. Twenty-two samples of water were collected and analyzed for chemical constituents by the U. S. Geological Survey laboratory in Ocala, Florida.

Twenty-nine holes were augered for a total footage of 1,656 feet; gamma-radiation logs were made of 62 dug and bored wells totaling 1,911 feet of hole; and surface outcrops. were examined. 
The limestone aquifers were studied by examining samples of rock cuttings collected by well drillers as they constructed water wells in the county. Samples from 12,308 feet of hole were examined. In addition, seven test wells totaling 1,855 feet of hole were drilled in Cook County in areas where additional data were needed. Gamma-radiation, electrical resistivity, and self-potential logs were made in all test wells and in as many water wells as were available. Twenty-one wells totaling 3,228 feet of hole were logged.

\section{Well Numbers}

The field well-numbering system used in this report is based upon geographic coordinates. Each well is assigned two numbers separated by a letter. The first number and the letter refer to the coordinate system shown in figure 1 and identifies the individual $71 / 2$ minute quadrangle in which the well is located. The final number represents the well numbered serially within a quadrangle. Accordingly, well $18 \mathrm{G} 18 \mathrm{w}$ s the 18 th well to be inventoried within the $7 \frac{1}{2}$ minute quadrangle represented by coordi is 18 and $G$. Locations of wells inventoried during this study are shown in figure 1.

Wells for which drill cuttings are available have also been given a Georgia Geological Survey (GGS) number. These numbers are given in table 4 under "well numbers" and in table 6 under "remarks". Drill cuttings from these wells and other data collected during this study are on file in the sample library of the Georgia Department of Mines, Mining and Geology in Atlanta.

\section{Acknowledgments}

This investigation was made by the U. S. Geological Survey in cooperation with the city of Adel, Cook County, and the Georgia Department of Natural Resources, Earth and Water Division.

Acknowledgment is due Mr. S. H. Sutton, superintendent of the city of Adel Water and Gas Department, for his assistance with test drilling and pump testing; Mr. John Flatt, manager of Layne-Atlantic Drilling Company in Albany, Ga.; Mr. John Carr, owner of Carr Drilling Company in Valdosta, Ga.; Mr. Dayton Everetts, owner of Everetts Drilling Compaily in Lake Park, Ga.; for supplying well data and formation logs.

\section{WATER-QUALITY STANDARDS}

The mineral content of ground water generally is controlled by the lithology of the aquifer, or rock, in which the water is contained. Water obtained from a limestone contains appreciable calcium and bicarbonate because limestone is composed of the mineral, calcium carbonate. If the limestone contains dolomite, a magnesium calcium carbonate, its water will contain appreciable magnesium and calcium and bicarbonate. If the limestone contains gypsum, its water will contain appreciable calcium and sulfate. If the aquifer is a quartz sand, then its water will contain appreciable silica. The following additional minerals are known to affect the ciremical quality of water in aquifers in southwest Georgia: common salt (sodium chloride), pyrite and marcasite (iron sulfides), glauconite (potassium iron silicate), and apatite (calcium phosphate containing fluoride).

The U. S. Public Health Service (1962) has established water-quality standards to be used in interstate commerce and suggests that these be applied to public water systems. Their recommended limits are given in table 1 and a brief discussion of the various constituents follows: Water containing concentrations in excess of those listed in table 1 ordinarily should not be used unless no other suitable supply can be obtained.

Table 1. - Drinking water standards. (From U.S. Public Health Service, 1962).

\begin{tabular}{|l|c|}
\hline Chemical Constituent & $\begin{array}{c}\text { Rceommended Maximum Concentration } \\
\text { (milligrams per liter) }\end{array}$ \\
\hline Iron (fe) & 0.3 \\
Sulfate $\left(\mathrm{SO}_{4}\right)$ & 250 \\
Chloride $(\mathrm{Cl})$ & 250 \\
Nitrate $\left(\mathrm{NO}_{3}\right)$ & 45 \\
Fluoride $(\mathrm{F})$ & 1.2 \\
Dissolved solids & 500 \\
\hline
\end{tabular}


Iron is present in small amounts in most ground water but the recommended limit for domestic use is $0.3 \mathrm{mg} / 1$ (milligram per liter). Water containing more than $0.3 \mathrm{mg} / \mathrm{l}$ will stain fabrics, utensils, and fixtures, and $0.5 \mathrm{mg} / \mathrm{l}$ is detectable by taste. Also, water having a high iron content favors growth of the organism Crenothrix which forms rust-colored deposits in water pipes and fixtures, partly or completely clogging them. Excessive iron may be removed from most water by aeration and filtration.

\section{Sulfate}

Most sulfate in ground water is derived from sulfur-bearing minerals such as gypsum, pyrite or marcasite, in the rocks, but sulfate also can be derived from sulfur-bearing organic compounds and from fertilizers containing sulfate.

Sulfate is purgative and causes a bitter taste in water if present in excess of $250 \mathrm{mg} / 1$. Sulfate in excess of $100 \mathrm{mg} / \mathrm{l}$ causes hard scale in boilers if calcium and magnesium cations are also present.

\section{Chloride}

Sodium chloride is a characteristic constituent of sewage, and any appreciable pollution of water by sewage is accompanied by a measurable increase in chloride. Chloride also is dissolved from sodium chloride minerals contained in some rocks. Chloride gives a salty taste to water if present in quantities greater than about $400 \mathrm{mg} / \mathrm{l}$. The recommended limit for drinking water is $250 \mathrm{mg} / \mathrm{l}$.

\section{Nitrace}

Fertilizers contribute to the nitrate content of water in shallow aquifers and some nitrogen is dissolved from rocks; but most of the nitrate in water is considered to be the oxidation product of nitrogenous organic material (usually sewage or fertilizer). The presence of abnormal quantities of nitrate may indicate poor sanitary conditions.

The so-called "blue baby" disease (metheglobinemia or cyanosis) in infants is a possible hazard when the baby's feeding formulas are mixed with water containing more than 45 $\mathrm{mg} / \mathrm{l}$ of nitrate which is the recommended maximum limit.

\section{Fluoride}

Fluoride is a natural constituent in much of the ground water in southwestern Georgia. It is dissolved from numerous complex fluoride-bearing minerals found in the rocks, the most important of which is apatite. The recommended maximum limit for fluoride content in water is based upon the average maximum air temperature. Thus, in the report area the recommended maximum concentration is $1.2 \mathrm{mg} / 1$; recommended minimum is $0.7 \mathrm{mg} / 1$ and optimum is $0.9 \mathrm{mg} / \mathrm{l}$. Fluoride in excessive concentracions is undesirable in water used for drinking because it may cause spotting of the tooth enamel and may affect skeletal bone structure.

\section{AQUIFERS AND THEIR HYDRAULIC PROPERTIES}

Within the Georgia Coastal Plain, aquifers (water-bearing zones) function both as storage reservoirs and as pipelines that transmit ground water from areas where it enters the ground to areas where it is discharged. In Cook County, wells that tap these aquifers obtain most of their water from a few inin, highly permeable zones capable of transmitting large volumes of water, and not from the entire thickness of the rocks. Knowing the depth, thickness, distribution, and yield of these zones as well as their hydraulic properties, allows for the proper construction and spacing of wells. Water wells drilled in Cook County, although they may tap one or more of these aquifers, locally are called either "deep", "semi-deep", or "shallow" depending upon the major aquifer thisy tap.

The "deep" drilled wells tap a system of limestones of Eocene to Miocene age referred to in this and most previous reports as the principal artesian aquifer, the most extensively used aquifer system in Georgia. Three geologic formations make up this aquifer system in the study area. They are the Ocala Limestone of late Eocene age, and the Marianna and 
Suwannee Limestones of Oligocene age. This aquifer system is tapped by all municipal and irrigation wells and many domestic wells in Cook County.

The "semi-deep" drilled wells tap the Tampa Formation of early Miocene age. In the southern part of Cook County, this aquifer is tapped by a few irrigation and municipal wells. Because the Tampa yields sand when pumped from unscreened wells, it is usually cased off in municipal and irrigation wells. In the northern part of Cook County, it is separated from the principal artesiar aquifer by silt, clay, and sandy limestone of lower permeability; here, the Tampa is tapped by domestic and stock wells and it usually yields sandfree water of good quality.

The "shallow" bored and Jug wells tap whichever formation occurs at shallow depths below land surface where the well is constructed. Yield of these wells varies greatly. Those that tap an upper permeable zone are capable of yielding several hundred gpm (gallons per minute) while some of those tapping the tight lower zone reportedly yield less than $1 \mathrm{gpm}$.

The stratigraphic position and thickness of the water-bearing zones in an aquifer can be determined by monitoring a well that taps the aquifer with a current meter while water either is being pumped out of or into the well at a constant rate. A current meter consists of a helical vane mounted on a pivot and placed in an openend tube through which the water moves. The revolutions per minute of the vane indicate the velocity of the water. If the well diameter and the rate of pumpage are known, the volume of flow at various depths can be estimated and the depth. thickness, stratigraphic position. and volume of water supplied by each water-yielding zone can be determined. The volume of flow generally can be controlled by valves or pump speed and measured with a meter. The diameter of a well can be determined by use of a caliper designed for use inside of wells. A graph recorded with such an instrument is called a hole-gage, well-diameter, or caliper log.

The position of each water-bearing zone with reference to the various stratigraphic formations is determined by examining samples of the rocks penetrated by the well or comparing the electrical and gamma-radiation properties of the rocks with rocks in other wells to locate the tops and bottoms of the formations.

The principal hydraulic properties of an aquifer are its transmissivity $(T)$ and storage coefficient (S). A measure of a formation's ability to transmit ground water is its transmissivity, which is defined as the rate of flow of water in gallons per day, through a vertical strip of the aquifer 1 foot wide and extending the full saturated thickness under a hydraulic gradient of 100 percent ( 1 foot per foot). The storage properties of an aquifer are expressed by the storage coefficient, which is defined as the volume of water released from storage per unit surface area of the aquifer per unit decline in head or water level. The transmissivity and storage coefficient of an aquifer may be determined by means of aquiferperformance tests wherein the effect of pumping a well at a known constant rate is measured the pumped well and at nearby observation wells penetrating the aquifer.

Graphs of drawdown versus time after pumping started or recovery versus time after pumping stopped, are used to solve equations which xpress the relation between the transmissivity and storage coefficient of an aquifer and the lowering of water levels in the vicinity of a pumped well (Theis, 1935; Cooper and Jacob, 1946; and Jacob, 1950).

When a well is pumped water levels decline in a funnel shape called a cone of depression, with the greatest drawdown at the pumped well. With other factors remaining constant, the higher the transmissivity the less the water-level drawdown and the shallower the cone of depression. Similarly, the greater the storage coefficient the less the water-level decline required to obtain the amount of water being pumped from storage. With continuous pumping, water is taken from storage at greater distances from the pumped well and the cone of depression grows in size and depth until, or unless, a source of recharge equal to the pumpage is intercepted. In this event, a state of equilibriui: is reached. Waterlevel decline, or drawdown, is directly proportional to the pumping rate and diminishes in a logarithmic manner outward from the pumped well.

In a multiple-well system, such as supplies the city of Adel, a cone of depression is formed around each pumped well. When the cones, or pumping effects, orerlap, the wells are said to interfere and water levels decline in a manner directly proportional to the pumping rates and inversely proportional to the logarithm of the distance between wells.

Hydraulic properties determined for an aquifer can be used to evaluate, for different . pumping rates, the magnitude of interference between theoretical wells located nearby that tap this same aquifer. 


\section{GEOLOGIC FORMATIONS AND THEIR WATER-BEARING PROPERTIES}

Rocks in Cook County probably contain potable (drinking) water to a depth of only about 400 to 500 feet. However, the water contained in the rocks to a depth of about 1.400 feet probably could be treated and used in an emergency. The rocks below 1,400 feet probably contain highly mineralized water.

The Lake City Limestone of middle Eocene age is believed to be the lowermost aquifer in Cook County that contains water which can be treated and used. It is a coarsely glauconitic. fossiliferous cream to brown colored limestone. It is about 200 feet thick and should occur in Cook County at about 1,200 to 1,400 feet below land surface. At Thomasville, Ga., located 25 miles southwest of Cook County, it contains mineralized water with $24,218 \mathrm{mg} / \mathrm{l}$ dissolved solids (Sever, 1966), and i- Cook County it probably contains water of similar quality. Thus, demineralization of water from the Lake City would be required before it could be used for most purposes.

The Avon Park Limestone, also of middle Eocene age, overlies the Lake City. It is about 300 feet thick and occurs at about 900 to 1,100 feet below land surface. It is a limestone that is cream to brown, sandy, glauconitic, and at places, dolomitic. It reportedly yields moderate amounts of water to wells in the southeast Georgia area, but no information is available about its yield in Cook County. It could yield small to moderate amounts of slightly mineralized water in Cook County, but it is not considered to be a reliable aquifer.

The Ocala Limestone of late Eocene age overlies the Avon Park Limestone. It is about 500 feet thick and its top occurs at about 400 to 600 feet below land surface. It is a cream-colored nodular fossiliferous limestone interbedded with gypsum and orange saccharoidal dolomite. It is capable of yielding large volumes of very hard water containing amounts of dissolved sulfate, iron. and magnesium that exceed the recommended maximum limits for municipal use. (See table 1.) The few irrigation or municipal wells in Cook County that yield sulfur water tap this formation.

The Marianna Limestone of middle Oligocene age overlies the Ocala Limestone in Cook County. At Adel, the Marianna occurs at a depth of about 370 feet below land surface. The Marianna is about 50 feet thick and consists of white, nodular, pyritic limestone. It contains abundant water of good quality. It is the lowermost formation in Cook County known to contain good water, but this water is restricted to the upper few feet near the contact with the Byram Formation.

The Byram Formation of middle Oligocene age overlies the Marianna Limestone in Cook County. It is about 10 to 40 feet thick and underlies the couniy at depths from about 360 feet near Adel to about 500 feet near Lenox. It consists of dense, brownish gray dolomite.

The Suwannee Limestone of Oligocene age overlies the Byram Formation. It is about 160 feet thick and occurs at depths of about 200 to 400 feet below land surface. It is a white, rather pure, fossiliferous limestone and supplies most of the water pumped from wells in Cook County. It is capable of supplying large quantities of hard to very hard water of a quality suitable for municipal, irrigation, and most industrial uses.

The Tampa Formation of early Miocene age overlies the Suwannee Limestone and occurs at depths of 150 to 300 feet below land surface. It varies in thickness from about 40 feet in the southern part of Cook County to more than 100 feet in the northern part. It consists of light gray, extremely dense, cherty, sandy limestone. It contains appreciable moderately hard water of good quality; however, in some places wells developed by the open hole method in this formation yield a mixture of water and very fine-grained sand. The Tampa Formation is tapped by the "semi-deep" wells, most of which are in the northern part of Cook County.

As mapped by MacNeil (1947), the Hawthorn Formation overlies the Chipola Formation. The author believes that the Hawthorn Formation as mapped in Cook County may not be equivalent to the type section in Florida. For this reason the term, Miocene undifferentiated, has been used in the well logs.

The lower unit overlies the Tampa Formation. It crops out along the major streams in Cook County. (See fig. 2) It is about 75 to 100 feet thick and consists of yellowish-gray fine-grained quartz sand and yellowish-green sandy clay. It yields little or no water to wells and acts as the principal confining layer for water in the underlying limestones. This upper unit crops out over most of Cook County but has been eroded near many of the stream channels. At places it is as much as 85 feet thick and it consists of orange to red, clayey, hematitic, phosphatic medium- to very coarse-grained quartz sand. It is capable of supplying 




Figure 2. - Geologic map and configuration of the top of Suwannee Limestone. 
moderate amounts of water suitable for domestic, irrigation, and most industrial uses. Many dug and bored wells in Cook County tap this formation. The water at most places is corrosive and high in dissolved iron. At a few places it probably is polluted.

Alluvial deposits of Pleistocene to Holocene age overlay the Hawthorn and Chipola rornat:ons along the major streams. They consist of white to cream quartz sand and gravel. Maximum thickness is about 25 feet. They contain moderate amounts of corrosive water and are tapped by a few dug and bored wells.

\section{U. S. GEOLOGICAL SUI.VEY TEST WELL AT ADEL Geologic Formations Penetrated}

A test well $(18 \mathrm{H} 16)$, located near the corner of West Second Street and North Elm Street in Adel, (fig. 3) was drilled to a depth of 865 feet and cased to a depth of 207 feet with 8-inch casing. Samples of the rocks penetrated by this well were coliected and studied to determine the thickness, lithology, and depth below land surface of each geologic formation. The author's desc ptions of these samples are given below, along with Foraminifera identified by $\mathbf{S}$. M. Herrick:

\section{Description}

Thickness Depth (feet) (feet)

MIOCENE SERIES (undifferentiated)

Sand: yellowish gray $(5 \mathrm{Y} 8 / 1)$, medium- to very coarse-grained, angular, poorly sorted, clear quartz; argillaceous material sparse

Sand: pale reddish brown $(10 \mathrm{R} 5 / 4)$ to pale red $(10 \mathrm{R} 6 / 2)$, fine to very coarse grained, subangular to rounded, poorly sorted, clear quartz; hematite common;

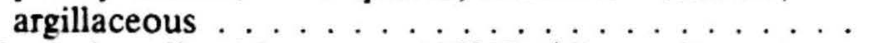

Sand: dark yellowish orange (10YR6/6), medium- to very coarse-grained, subangular to subrounded, fairly well sorted, clear quartz, stained quartz common, dark opaque grains common, phosphate pellets sparse; argillaceous material common . . . . . . . . .

Sand: yellcwish gray ( $5 Y 8 / 1)$, fine-grained, subangular, well sorted, clear quartz, feldspar common; argil-

$$
\text { latl sorted, clear quartz, feldspar common, argit- }
$$

TAMPA FORMATION

Sandstone: white (N9), fine- to coarse-grained, subrounded, failry well sorted, clear quartz, dark opaque minerals sparse to common, strong to weak calcareous cement; lignite common at 155 to 165 ; chert common at 160 to 175 ; fossil fragments rare

Dolomite: moderate yellowish brown (10YR5/4), saccharoidal

Limestone: white (N9), porous, fossiliferous, firm calcareous cement

Asterigerina subacuta at $205-210$

Pararotalia mexicana var., Asterigerina subacuta at $215-220$

Limestone: white (N9), very fossiliferous (almost a microcoquina), weak calcareous cement .........

Lepidocyclina sp. and Dictyoconus sp. at 285-323 


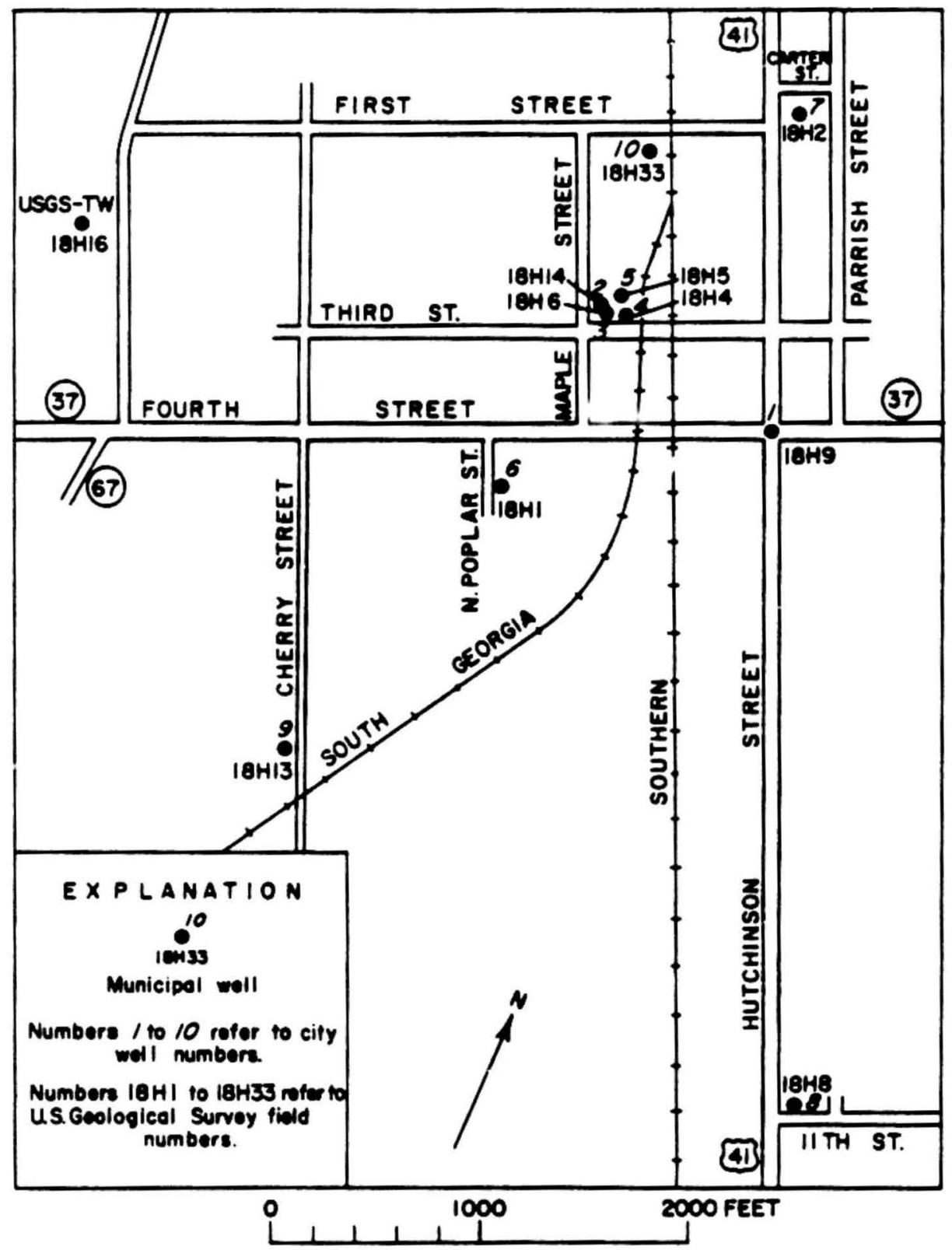

Figure 3. - Well locations at Adel. 


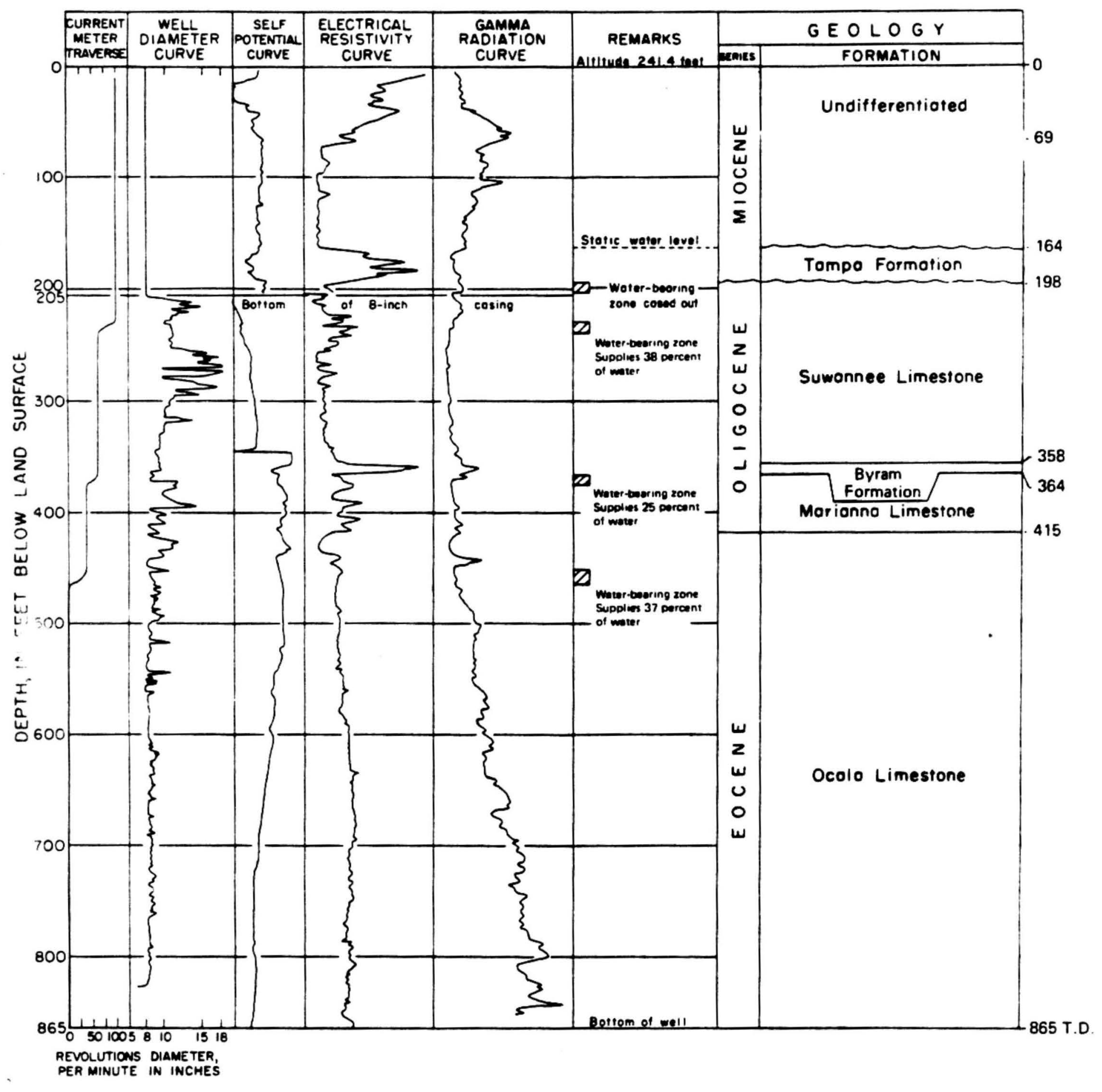

Figure 4. - Geophysical logs and distribution of water-bearing zones at Adel (well 18H16). 
Limestone: pinkish gray (5YR8/1) to white (N9), weak calcareous cement, fossiliferous

Dictyoconus sp. common

BYRAM FORMATION

Dolomite: light brownish gray $(5$ YR6/1), dense . . . .

Thickness

(feet)

38

8

Limestone: white (N9) to yellowish gray (5Y8/1), fossiliferous, pyritic, iron nodules common .... .

EOCENE SERIES

OCALA LIMESTONE

Limestone: white (N9), nodular, fossiliferous, Bryoza abundant . . . . . . . . .

Heterostegina ocalana at $416-420$

H. ocalana, Asterocyclina nassauensis at $420-425$

Dolomite: very pale orange $(10 \mathrm{YR} 8 / 2)$ to pale yellowish brown (10YR6/2), saccharoidal, iron stained fragments abundant at 515

Dolomite and gypsum(?): very pale orange (10YR8/2) to white (N9), soft flaky white gypsum(?) very

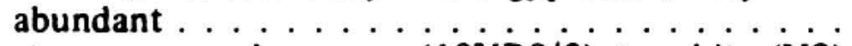

Limestone: very pale orange (10YR8/2) to white (N9), nodular, dense, fossiliferous . . . . . . . . .

Nummulites striatoreticulatus, Amphistegina

pinarensis var. at $576-580$

Limestone: white (N9), chalky, soft, fossiliferous . .
80

55

125

$165+$
521

576

701

Depth

(feet)

361

369

416

41

865

Remarks: The interval from 820 to 860 caved badly and had to be cemented before the well could be drilled deeper. After about 6 months, the well had filled back to a depth of 850 feet.

To correlate geologic units and to help locate water-bearing zones, current-meter, welldiameter, self-potential, electric-resistivity, and gamma-radiation logs were made in the 865 foot deep test hole. The results of these logs are shown in figure 4.

\section{Location of Water-Bearing Zones}

While constructing the Adel test well, the driller noted mud loss as he penetrated the Tampa Formation and lost all circulation in the top of the Suwannee Limestone at a depth of 200 feet. This water-bearing zone was sealed out of the well when the casing was installed. After completing the well at a depth of 865 feet, the interval from 207 to 865 feet was traversed by a current meter while about $450 \mathrm{gpm}$ was being injected into the well through a fire hose. The purpose was to Ir cate any water-bearing zones tapped by the well.

Three zones were located as shown in zure 4 and listed in table 2 . About 38 percent of the water entering the well moved out into the Suwannee Limestone between depths of 228 and 236 feet. Twenty-five percent of the water entered the water-bearing zone at the top of the Marianna Limestone between 365 and 268 feet. The remainder entered the Ocala Limestone between 456 and 462 feet.

No water-bearing zones weic found between 462 and 865 feet. The caliper log shows that below about 470 feet the rocks are not cavernous and the electric resistivity and selfpotential logs suggest that their permeability is low.

The yield from each zone when the pumping level is at 200 feet below land surface (near the bottom of the casing) is given in table 2. Also given are the estimated maximum yields for each zone. 
Table 2. - Location and yield of water-bearing zones at Adel, Ga.

\begin{tabular}{|c|c|c|c|c|c|c|c|c|c|c|c|c|c|}
\hline \multirow{2}{*}{$\begin{array}{l}\text { GEOLOGIC } \\
\text { FORMATION }\end{array}$} & \multicolumn{3}{|c|}{$\begin{array}{l}\text { Descriy tion of } \\
\text { water beer ing zones }\end{array}$} & \multicolumn{2}{|c|}{$\begin{array}{l}\text { Pocker Sottings } \\
\text { (feot below land } \\
\text { surfacel }\end{array}$} & \multicolumn{4}{|c|}{$\begin{array}{l}\text { Chomical Data } \\
\text { (milligrams per } \\
\text { liter) }\end{array}$} & \multirow{2}{*}{$\begin{array}{l}\text { Specific } \\
\text { capecity } \\
\text { lealloms per } \\
\text { minute per } \\
\text { tootl }\end{array}$} & \multirow{2}{*}{$\begin{array}{l}\text { Estimated per. } \\
\text { cent of total } \\
\text { woll yield sup. } \\
\text { plied by each } \\
\text { zono }\end{array}$} & \multirow{2}{*}{$\begin{array}{l}\text { Estimated } \\
\text { yield at } \\
\text { pumping lovel } \\
\text { of } 200 \text { foot } \\
\text { (eelloms per } \\
\text { minuto) }\end{array}$} & \multirow[t]{2}{*}{$\begin{array}{l}\text { Estimated maximum } \\
\text { vield from zono } \\
\text { (eollons por minute) }\end{array}$} \\
\hline & $\begin{array}{l}\text { Depth } \\
\text { to } \\
\text { top } \\
\text { (foet) }\end{array}$ & $\begin{array}{l}\text { Altitude } \\
\text { of } \\
\text { top } \\
\text { (feet) }\end{array}$ & \begin{tabular}{|l} 
Thick. \\
ness \\
(foent)
\end{tabular} & Top & Bottom & Iron & Sulfate & Herdnews & $\begin{array}{l}\text { Dissolved } \\
\text { solids }\end{array}$ & & & & \\
\hline $\begin{array}{l}\text { Suwannoe } \\
\text { Limestone }\end{array}$ & 228 & 13 & 8 & 227 & 243 & 0.31 & 256 & 376 & 515 & 31 & 38 & 1.100 & 1,900 \\
\hline $\begin{array}{l}\text { Marianna } \\
\text { Limestone }\end{array}$ & 365 & -124 & 3 & 362 & 378 & 0.23 & 262 & 380 & 524 & 21 & 25 & 700 & 2,100 \\
\hline $\begin{array}{l}\text { Ocsle } \\
\text { Limestone }\end{array}$ & 456 & .215 & 6 & 452 & 468 & 1.0 & 612 & 120 & 1.020 & 31 & 37 & 1.100 & 9,000 \\
\hline
\end{tabular}




\section{Quality of Water}

Each water-bearing zone tapped by the Adel test well, after being isolated with pneumatic packers, was pumped to determine the quality of its contained water. Chemical analyses of water from these zones are included further on in this report in table 4 , but partial chemical analyses and the packer settings are given in table 2 . These analyses show that the Ocala Limestone contains highly mineralized water that exceeds the recommended maximum concentrations of dissolved iron, sulfate, and total solids. Also, it is extremely hard $(720 \mathrm{mg} / \mathrm{l})$. Chemical analyses of water from nearby municipal wells show that water from the Suwannee and Marianna Limestones contains concentrations less than the recommended maximum for drinking water. The high dissolved solids from the upper two zones in the Adel test well are thought to be caused by leakage around the lower packer of water from the Ocala Limestone.

\section{HYDROGEOLOGY OF THE PRINCIPAL ARTESIAN AQUIFER}

Most wells drilled in Cook County tap either the Suwannee Limestone or both the Suwannee and Marianna Limestones. These two limestones constitute the upper part of what has been called the principal artesian aquifer in south Georgia and they yield abundant hard water of good quality throughout the county. A few wells are dirilled deep enough to tap the Ocala Limestone in the lower part of the principal artesian aquifer, but these wells generally yield extremely hard, mineralized water of poor quality.

The upper surface of the Suwannee Limestone is somewhat irregular. Figure 2 shows the altitude of the top of the Suwannee Limestone in Cook County. The top ranges from about 500 feet above mean sea level in southeastern and southwestern Cook County to more than 100 feet below mean sea level in extreme northern Cook County.

The city of Adel, the largest user of water in Cook County, pumped an average of about 600,000 gallon per day from this aquifer in 1966.

\section{City of Adel}

\section{History of Well Construction}

Data on history and characteristics of municipal wells at Adel are summarized in table 3 and their locations shown on figure 3.

The city of Adel drilled its first municipal well (well 1 in table 3 and fig. 3) in 1893. It was drilled to a depth of 280 feet and cased to an unrecorded depth with $4 \frac{1}{2}$-inch casing. Its water reportedly came from a limestone bed 229 feet below land surface and rose under artesian pressure to within 154 feet of land surface. Mr. J. B. Spencer of Lumber City (McCallie, 1898, p. 153) kept the following record of the material penetrated by this well:
1. Sandy soil
2. Red clay
3. White sand
4. Blue clay with sandstone boulders
5. Fine white sand
6. Limestone with thin layers of flint
2 feet
10 feet
10 feet
125 feet
25 feet
100 feet

Well 1, located near the center of the intersection of Fourth Street and North Hutchinson Avenue, was abandoned about 1907 and later destroyed when the streets were paved.

Adel's second well (well 2, table ") was drilled in 1907, at the city water works on West Third Street by White Company, to a depth of 675 feet (Stephenson and Veatch, 1915, p. 144). It was cased to a depth of 60 feet with 10-inch casing. Stephenson and Veatch reported that the static water level was only 50 feet below land surface in 1907, but this probably is a typographical error. Records of other wells in the area suggest that the static level should have been about 150 feet below land surface. Upon completion, this well yielded about $500 \mathrm{gpm}$ of water which was very hard and contained $518 \mathrm{mg} / \mathrm{l}$ sulfate and $972 \mathrm{mg} / \mathrm{l}$ dissolved solids. This well was abandoned in 1925 because of its poor water quality. 
Table 3. -- Construction data for municipal wells at Adel, Ga.

\begin{tabular}{|c|c|c|c|c|c|c|c|c|c|c|c|c|}
\hline \multirow{2}{*}{$\begin{array}{l}\text { City } \\
\text { Well } \\
\text { Number }\end{array}$} & \multirow[t]{2}{*}{ Location } & \multirow[t]{2}{*}{ Driller } & \multirow[t]{2}{*}{ Date Drilled } & \multirow{2}{*}{$\begin{array}{l}\text { Anitude } \\
\text { of Iend } \\
\text { suriece } \\
\text { (feet) }\end{array}$} & \multirow{2}{*}{$\begin{array}{l}\text { Well } \\
\text { Depth } \\
\text { (fost) }\end{array}$} & \multicolumn{2}{|c|}{ Cesing } & \multirow{2}{*}{$\begin{array}{l}\text { Depth } \\
\text { to } \\
\text { water } \\
\text { (leet) }\end{array}$} & \multirow{2}{*}{$\begin{array}{l}\text { Specific } \\
\text { Cepecity } \\
\text { (gpm/tt) }\end{array}$} & \multirow{2}{*}{$\begin{array}{l}\text { Field } \\
\text { Number }\end{array}$} & \multirow{2}{*}{$\begin{array}{l}\text { Georgia } \\
\text { Geological } \\
\text { Survey } \\
\text { Number }\end{array}$} & \multirow[t]{2}{*}{ Pemarks } \\
\hline & & & & & & $\begin{array}{l}\text { Size } \\
\text { (inches) }\end{array}$ & $\begin{array}{l}\text { Amount } \\
\text { (feet) }\end{array}$ & & & & & \\
\hline 1 & $\begin{array}{l}\text { Intersection of Fourth } \\
\text { Street and North } \\
\text { Hutchinson Avenue }\end{array}$ & Unknown & 1893 & 246.0 & 280 & 4.5 & ? & 154 & $\cdots$ & $18 \mathrm{H} 9$ & $\ldots$ & $\begin{array}{l}\text { Well destroyed, See } \\
\text { Stephenson and Veatch } \\
\text { (1915,p. 145) and McCallia } \\
\text { (1898, p. 153) }\end{array}$ \\
\hline 2 & $\begin{array}{l}\text { Northwesternmost well } \\
\text { at Adel Water Works on } \\
\text { West Third Street }\end{array}$ & White and Co & 1907 & 240.3 & $6 \cdot \overline{5}$ & 10 & 60 & 150 & $\ldots$ & $18+14$ & $\cdots$ & $\begin{array}{l}\text { Well destroyed, See } \\
\text { Stephenson and Veatch } \\
\text { (1915, p. 145) }\end{array}$ \\
\hline 3 & $\begin{array}{l}\text { Southwesternmost well } \\
\text { at Adel Water Works on } \\
\text { West Third Street }\end{array}$ & $\begin{array}{l}\text { J.R. Connelly } \\
\text { Co. }\end{array}$ & 1925 & 240.4 & 400 & 128 & $?$ & 153 & $\ldots$. & 1846 & $\ldots$ & $\begin{array}{l}\text { Well abandoned and filled } \\
\text { with dirt }\end{array}$ \\
\hline 4 & $\begin{array}{l}\text { Southeasternmost well } \\
\text { at Adel Water Works on } \\
\text { West Third Street }\end{array}$ & $\begin{array}{l}\text { Gray Well and } \\
\text { Pump Crs. }\end{array}$ & 1931 & 240.8 & 358 & 10 & 171 & 159 & $\ldots$ & $18 \mathrm{H} 4$ & $\cdots$ & Do \\
\hline $\mathbf{5}$ & $\begin{array}{l}\text { Northeasternmost well } \\
\text { at Adel Water Works on } \\
\text { West Third Street }\end{array}$ & $\begin{array}{l}\text { Layne-Atlantic } \\
\text { Co. }\end{array}$ & 1940 & 240.0 & 375 & 12 & 213 & 160 & $\cdots$ & $18 \mathrm{H5}$ & 39 & \\
\hline 6 & $\begin{array}{l}\text { On Poplar Street between } \\
\text { Fourth and Fifth Streets }\end{array}$ & Do & 1943 & 240.0 & 376 & 12 & 211 & $\ldots$ & $\cdots$ & $18 \mathrm{H1}$ & $\ldots$ & $\begin{array}{l}\text { Well abendoned and filled } \\
\text { with dirt }\end{array}$ \\
\hline 7 & $\begin{array}{l}100 \text { feet southeast of } \\
\text { the corner of Carter } \\
\text { Street and North } \\
\text { Hutchinson Avenue }\end{array}$ & Do & 1946 & 242.2 & 386 & 12 & 231 & 156 & $\ldots$ & 18H2 & 122 & See Herrick (1981, p. 137) \\
\hline 8 & $\begin{array}{l}\text { Corner of Eleventh } \\
\text { Street and South } \\
\text { Hutchinson Avenue }\end{array}$ & Do & 1957 & 240.0 & 359 & $\begin{array}{l}16 \\
12\end{array}$ & $\begin{array}{l}0-46 \\
46.253\end{array}$ & 154 & 200 & $18 н 8$ & 682 & \\
\hline 9 & $\begin{array}{l}\text { On South Cherry } \\
\text { Street } 200 \text { feet north of } \\
\text { the South Georgia } \\
\text { Pailroad }\end{array}$ & Do & 1961 & - & 359 & 12 & 221 & 165 & 37 & $18 \mathrm{H13}$ & -- & \\
\hline 10 & $\begin{array}{l}\text { On West First Street } \\
100 \text { feet west of the } \\
\text { Southern Railroad }\end{array}$ & Do & 1964 & 240.0 & 390 & 18 & 207 & 170 & 325 & $18 \mathrm{H33}$ & 1218 & $\begin{array}{l}\text { Electric, Resistivity, Gemmo- } \\
\text { ray and current meter logs } \\
\text { mode }\end{array}$ \\
\hline
\end{tabular}


Well 3, located at the city water works about 70 feet south of well 2 , was drilled in 1925 by J. R. Connelly Drilling Company to a depth of 400 feet and cased to an unknown depth with 12 -inch steel casing. At a later date, 8-inch casing was seated inside the 12-inch casing in an attempt to seal out some sand being pumped from the well. Well 3 was abandoned in 1931 and later filled.

Well 4, located at the city water works about 60 feet east of well 3, was drilled in 1931 by Gray Well and Pump Company to a depth of 358 feet and cased to a depth of 171 feet with 10-inch steel using. During construction, the driller described the materials penetrated by this well as follows:

$\begin{array}{lll}\text { Description } & \begin{array}{l}\text { Thickness } \\ \text { (feet) }\end{array} & \begin{array}{l}\text { Depth } \\ \text { (feet) }\end{array}\end{array}$

$\begin{array}{lrr}\text { Soil } & 1 & 1 \\ \text { Clay } & 13 & 14 \\ \text { Clay } & 31 & 45 \\ \text { Sandy clay } & 45 & 90 \\ \text { Gray marl } & 5 & 95 \\ \text { Sandy marl } & 5 & 100 \\ \text { Clay or fullers earth } & 45 & 145 \\ \text { Sand } & 10 & 155 \\ \text { White clay } & 15 & 170 \\ \text { Rock } & 15 & 185 \\ \text { Marl and rock } & 5 & 190 \\ \text { Marl and } & 20 & 210 \\ \text { Water bearing limes } & 148 & 358\end{array}$

The driller's log shows that the well penetrated marl below the casing between 185 and 210 feet. Well 4 pumped a mixture of marl and water for about 10 years then, in 1941, the marl caved into the well and the well was abandoned. It was later filled to land surface with dirt.

Well 5, located at the water works about 100 feet north of well 4, was drilled in 1940 by Layne-Atlantic Drilling Company to a depth of 375 feet and cased to a depth of 213 feet with 12-inch steel casing. The annular space between the casing and rocks was filled with cement. During construction, the driller described the materials penetrated as follows:

\section{Description}

\section{Top soil}

Fine sand and red clay

White sand

Red sandy clay, some sand

Soft clay

Hard gray clay

Soft gray clay

Hard clay

Gray clay and thin layers of rock

Hard rock, limestone

Hard, flinty limestone

Hard limestone

Medium hard limestone

Soft porous limestone

Very hard limestone

Drilling stopped in very hard, flinty limestone
Thickness $\quad$ repth

(feet)

(feet)

$\begin{array}{rr}3 & 3 \\ 11 & 14 \\ 3 & 17 \\ 53 & 70 \\ 8 & 78 \\ 6 & 84 \\ 17 & 101 \\ 6 & 107 \\ 63 & 170 \\ 4 & 174 \\ 26 & 200 \\ 14 & 214 \\ 6 & 220 \\ 151 & 371 \\ 4 & 375\end{array}$

Samples of the rocks penetrated by well 5 were collected by the driller to a depth of about 270 feet. At this depth, circulation of mud was lost into a permeable zone in the limestones and samples of the rock could no longer be collected. The samples were examined and described by S. M. Herrick (1961, p. 135, well no. GGS 39) as shown below: 
No Samples

IN MIOCENE (UNDIFFERENTIATED):

Clay: mottled, very sandy, limonitic . . . . . . . . . .

No samples.

Clay:yellowish-green, blocky, sandy, phosphatic, interbedded limestone, light-gray to white, dense, somewhat saccharoidal, sandy; sand, fine-grained, angular. phosphatic (finely disseminated) . . . . . . Gray polished, phosphatic pebbles prominent at 80 .

No samples

Dolomitic limestone: light-brown, extremely dense, crystalline, somewhat sandy: some limestone as above

No samples

IN OLIGOCENE (UNDIFFERENTIATED):

Limestone: light-gray to cream at depth, nodular, much calcitized, rather dense, cherty, fossiliferous (bryozoan remains and some Foraminifera) . . . . . .

Quinqueloculina sp., Dictyoconus sp. at 209-2091/2

Quinqueloculina sp., Rotalia mexicana var. at 270

$?$

24

209

In 1965 well 5 was still in use and yielded about $1,000 \mathrm{gpm}$ with a turbine pump, driven by a $100 \mathrm{hp}$ electric motor. On August 28,1941 the static water level was 153.8 feet below land surface but on September 29, 1964, it was 173.2 feet below land surface - a decline of 19.4 feet in 23 years.

In 1943 the city drilled its sixth well, selecting as a site the east side of Popular Street, about halfway between Fourth and Fifth Streets. Well 6 was drilled by Layne-Atlantic Drilling Company to a depth of 376 feet and cased to 211 feet with 12-inch steel casing. The annular space between the casing and rocks was filled with cement grout from 211 feet back to land surface. Between 211 feet and 376 feet, the well is open hole in limestone. During construction, the driller described the material penetrated by this well as shown below:

\section{Description

$\begin{array}{ll}\text { Thickness } & \begin{array}{l}\text { Depth } \\ \text { (feet) }\end{array}\end{array}$ (feet)}

Red sandy clay

Hard red clay

$\begin{array}{rr}10 & 10 \\ 35 & 45 \\ 65 & 110 \\ 10 & 120 \\ 1 & 121 \\ 15 & 136 \\ 22 & 158 \\ 11 & 169 \\ 6 & 175 \\ 3 & 178 \\ 12 & 190 \\ 6 & 196 \\ 15 & 211 \\ 7 & 218 \\ 1 & 219 \\ 3 & 222 \\ 4 & 226 \\ 62 & 288 \\ 12 & 300 \\ 18 & 318 \\ 11 & 329 \\ 37 & 366 \\ 10 & 376\end{array}$


Well 6 was sbandoned and filled to land surface with dirt prior to 1963 .

In 1946, the city drilled its seventh well selecting a site about 100 feet southeast of the corner of Carter Street and North Hutchinson Avenue. Well 7 was drilled by Layne Atlantic Drilling Company to a depth of 386 feet and cased to a depth of 231 feet with 12-inch steel casing. The annular space between the casing and rocks was filled with cement grout from 231 feet back to land surface. Between 231 feet and 386 feet the well is open hole in limestone. During construction, the driller described the material penetrated by this well as follows:

\section{Description}

Pink chalk and some sand, hard

Yellow sand

White clay

Flint rock and clay

Yellow clay

Hard clay, gray with streaks

Soft gray pink clay

Soft clay

Hard gray clay

Hard clay with rock

Clay with rock

Blue clay

Soft blue and pink clay

Hard blue clay

Softer clay and fine silky sand

Hard substance resembling limestone

Very hard

Hard substance resembling limestone

Hard rock

Clean sandrock

Very soft rock with blue sandrock

Hard streak

Soft fine blue sand

Hard limestone

Soft, used considerable amount of water

Medium hard limestone

Very hard limestone, almost a standstill at 262 feet

Very hard limestone

Limestone, rock medium hard with soft cavities

Very hard, drilled 2 hours and didn't move any

$\begin{array}{ll}\text { Thickness } & \begin{array}{l}\text { Depth } \\ \text { (feet) }\end{array} \\ \text { (feet) }\end{array}$

50

$12 \quad 62$

$20 \quad 82$

$11 \quad 93$

$5 \quad 98$

$2 \quad 100$

$6 \quad 106$

$6 \quad 112$

$5 \quad 117$

$6 \quad 123$

$11 \quad 134$

$8 \quad 142$

3145

$8 \quad 153$

$17 \quad 170$

$\begin{array}{ll}7 & 177\end{array}$

$1 \quad 178$

$1 \quad 179$

$4 \quad 183$

$15 \quad 198$

$10 \quad 208$

$1 \quad 209$

$3 \quad 212$

$8 \quad 220$

$5 \quad 225$

$5 \quad 230$

$32 \quad 262$

1263

$23 \quad 386$

386

The driller also collected samples of rocks penetrated by well 7 to a depth of 270 feet. Below 270 feet the rock samples were lost into a permeable zone in the limestones and could not be recovered. The samples later were examined and described by $\mathbf{S}$. M. Herrick

961 , p. 137, well no. GGS 122) as shown below:

Description

Thickness Depth

(feet)

(feet)

MIOCENE (UNDIFFERENTIATED):

Clay: mottled, very sandy, limonitic . . . . . . . . .

Clay: yellowish-green, blocky, sandy; interbedded

limestone at depth, white, dense, sandy; beds of sand, fine to coarse grained, angular ... . .

IN OLIGOCENE (UNDIFFERENTIATED):

Limestone: light-gray, nodular, dense, much calcitized, fossiliferous (some bryozoan remains and Forami-

nifera)

Rotalia mexicana var. at 231 
Upon completion of the well, the city installed a turbine pump driven by a $60 \mathrm{hp}$ electric motor which pumped about $700 \mathrm{gpm}$. Later, in 1962, this pump was replaced by another turbine pump driven by a $100 \mathrm{hp}$ electric motor which produced, $1,016 \mathrm{gpm}$ from the well with only 15 feet of water-level decline. In 1965 well 7 was still used by the city.

On June 19, 1946, the static water level was 156 feet below land surface but on September 29, 1964, it was 161. 4 feet below land surface - a decline of about 5.4 feet in 18 years.

In 1957 the city drilled its eighth well, selecting as a site the northeast corner of East Eleventh Street and South Hutchinson Avenue. Well 8 was drilled by Layne-Atlantic Drilling Company to a depth of 359 feet, cased to a depth of 46 feet with 16-inch steel casing, then cased from 46 feet to 253 feet with 12-inch steel casing. The annular space between the casing and rocks was filled with cement grout from 253 feet back to land surface. Between 253 and 359 feet, the well is open hole in limestone. During construction, the material penetrated by the well was described by the driller as shown below:

\section{Description}

Top Soil

Yellow sand and yellow and red clay

White and yellow clay

Fine white sand

Coarse white sand

Coarse sand and gravel

Coarse chalky sandy clay

Fine sandy chalky clay

Fine sandy pink and yellow clay

Yellow sandy clay

Yellow sandy clay

Pink, white and yellow sandy clay

Lavender and white and yellow clay

Yellow and white clay

Soft sandy yellow clay

Hard sandy yellow clay

Soft white sandy clay

Chalky white clay

Soft white clay

Fine white and brown sandstone

Soft white chalky clay

White sandstone

Fullers earth

Hard sandstone

Soft sandy white clay

Fine sandy white clay

Green limerock and sandstone, hard

Fine white sandy clay

Soft white limerock with streaks of sandstone

Soft gray limerock

Limerock with hard streaks

Very hard and soft limerock

\section{Thickness \\ (feet) \\ Depth \\ (feet)}

$\begin{array}{rr}5 & 5 \\ 8 & 13 \\ 2 & 15 \\ 8 & 23 \\ 13 & 36 \\ 6 & 42 \\ 5 & 47 \\ 5 & 52 \\ 5 & 57 \\ 5 & 62 \\ 5 & 67 \\ 5 & 72 \\ 5 & 77 \\ 17 & 94 \\ 3 & 97 \\ 12 & 109 \\ 25 & 134 \\ 10 & 144 \\ 20 & 164 \\ 2 & 166 \\ 27 & 193 \\ 1 & 194 \\ 2 & 196 \\ 5 & 201 \\ 11 & 212 \\ 7 & 219 \\ 10 & 229 \\ 12 & 241 \\ 9 & 250 \\ 10 & 260 \\ 46 & 306 \\ 29 & 335 \\ & \end{array}$


Samples of the rocks penetrated by well 8 (GGS $682 ; 18 \mathrm{H} 8$ ) were collected to a depth of 260 feet. Below 260 feet the rock samples were lost into a permeable zone in the limestones and could not be recovered. The samples collected were examined and described by the author as follows:

\section{Description}

\section{MIOCENE SERIES (Undifferentiated)}

Sand: very pale orange $(10 Y R 8 / 2)$ to grayish orange

(10YR7/4), medium to very coarse grained, subangular, poorly sorted; hematite sparse .... . .

Sand: grayish orange (10YR7/4), fine to coarse grained, subangular, argillaceous fairly well sorted; interbedded sandy clay . . . . . . . . . . . . .

Sand: grayish orange (10YR7/4), fine to coarse grained, subangular, phosphatic, poorly sorted, argillaceous; white polished phosphate pellets common ....

Clay: yellowish gray $(5 Y 7 / 2)$, fullers earth type, sandy; interbedded sand, fine to medium grained, subangular, well sorted, clear quartz .........

PARAROTALIA

Sand: white (N9), fine to medium grained, subangular, well sorted, clear quartz, weak argillaceous cement

Sandstone: white (N9) to very pale orange (10YR8/2), fine to medium grained, subangular, well sorted, firm siliceous cement . . . . . . . . . . . . . .

Sandstone: yellowish gray $(5 \mathrm{Y} 8 / 1)$, fine to medium grained, subangular, well sorted, weak to firm argillaceous cement . . . . . . . . . . . .

TAMPA FORMATION

Sand: white (N9) to yellowish gray (5Y8/1), fine grained, subangular, well sorted; interbedded sandstone and clay

Chert: yellowish gray $(5 Y 8 / 1)$, sandy

Sand: very pale orange (10YR8/2), very fine to fine grained, subangular, well sorted

\section{UNCONFORMITY}

\section{OLIGOCENE SERIES}

SUWANNEE LIMESTONE

Limestone: white (N9), fossiliferous, cherty, firm calcareous cement to firm siliceous cement ....

\section{Thickness Depth \\ (feet) \\ (feet)}

$\begin{array}{ll}15 & 15 \\ 67 & 82 \\ 25 & 107 \\ 10 & 117 \\ 20 & 137 \\ 10 & 147 \\ 19 & 166\end{array}$

26

$10 \quad 202$

11

213

20

No samples . . . . . . . . . . . . . . . . . 99
192

233

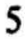

8

07

On July 8, 1957 this well was test pumped at $1,199 \mathrm{gpm}$ for 10 hours. During this test the water level declined only 6 feet. The test pump was removed and a turbine pump driven by a $100 \mathrm{hp}$ electric motor was installed. This combination was producing about 920 gpm in 1965.

The static water level on July 8,1957 was 154 feet below land surface. On September 29,1964 it was 155 feet below land surface - a decline of 1 foot in 7 years.

In 1961, Adel drilled its ninth well on South Cherry Street between Sixth and Eighth Streets. It was drilled by Layne-Atlantic Drilling Company to a depth of 359 feet and cased to a depth of 221 feet with 12-inch steel casing. The casing was cemented into place. Between 221 feet and 359 feet the well is open hole in limestone. The driller's description of the materials penetrated during construction is given below: 
Description

Topsoil

Fine sand

Red sandy clay

Red sand

Fine white sand

Gray clay

Red clay

Yellow clay, soft with some sand

Gray clay

Gray clay with hard streak of sand rock

Gray clay

Gray clay with small streak of sand rock

Blue clay

Blue clay with fine white sand

White clay with small streak of limerock

Brown limerock, hard

No sample

Flint rock, hard

Brown limerock, medium drilling

Brown limerock with hard streak

Brown limerock and clay

Hard brown limerock

No sample

Brown limerock, hard

Gray limerock

No returns - limestone $\begin{array}{ll}\text { Thickness } & \begin{array}{l}\text { Depth } \\ \text { (feet) }\end{array}\end{array}$

$\begin{array}{rr}1 & 1 \\ 2 & 3 \\ 3 & 6 \\ 4 & 10 \\ 2 & 12 \\ 12 & 24 \\ 15 & 39 \\ 22 & 61 \\ 17 & 78 \\ 12 & 90 \\ 12 & 102 \\ 20 & 122 \\ 21 & 143 \\ 21 & 164 \\ 4 & 168 \\ 3 & 171 \\ 2 & 173 \\ 13 & 186 \\ 9 & 195 \\ 12 & 207 \\ 2 & 209 \\ 7 & 216 \\ 2 & 218 \\ 7 & 225 \\ 11 & 236 \\ 123 & 359\end{array}$

Upon completion the well was test pumped at $1,120 \mathrm{gpm}$ for 8 hours. The static water level was 165 feet below land surface. During pumping, the water level declined 35 feet to a depth of 195 feet. Then the test pump was removed and the $60 \mathrm{hp}$ pump from well 6 was placed in this well. It supplies about $500 \mathrm{gpm}$ to the system.

To meet increased water demands, Adel drilled its tenth well in 1964. This well was drilled by Layne-Atlantic Drilling Company to a depth of 390 feet and cased to 207 feet, with 18 -inch steel casing. Cement grout fills the annular space between casing and rocks from land surface to 207 feet. The well is open hole in limestone from 207 to 390 feet. The driller's description of the material penetrated is given below:

\section{Description}

Yellow sandy clay

Fine sandy and yellow clay

Red and white clay

Yellow clay

Coarse brown sand and yellow clay

Yellow clay with little sand

Sandy yellow clay

Sandy white clay with some sandstone

Sandstone with little limestone

Limestone, sandstone and white clay

Sand, limestone and clay

Limestone with hard and soft streaks
Thickness

(feet)

$\begin{array}{rr}3 & 3 \\ 9 & 12 \\ 10 & 22 \\ 10 & 32 \\ 9 & 41 \\ 22 & 63 \\ 20 & 83 \\ 10 & 93 \\ 30 & 123 \\ 30 & 153 \\ 13 & 166 \\ 224 & 390\end{array}$

The driller collected samples of the rocks penetrated by well 10 (GGS $1218 ; 18 \mathrm{H} 33$ ) to a depth of 235 feet. The samples could not be recovered from below 235 feet. The samples from 0 to 235 feet are described below: 
MIOCENE SERIES (Undifferentiated)

Sand: white (N9) to very pale orange (10YR8/2),

fine to coarse grained, subangular, fair sorted;

hematite common; phosphate common at

63-83

Sandstone: white (N9) to yellowish gray (5Y8/1), fine

grained, subangular, well sorted; weak calcareous

cement . . . . . . . . . . . . . . . .

TAMPA FORMATION

Dolomite: pale yellowish brown (10YR6/2), saccharoidal, sandy, firmly cemented; interbedded white, sandy,

fossiliferous limestone. . . . . . . . . . . . .

\section{OLIGOCENE SERIES}

SUWANNEE LIMESTONE

Limestone: white (N9), pure, fossiliferous . . . . . 20

No samples .................. 158

On November 18,1964, well 10 was test pumped at $1.571 \mathrm{gpm}$ for 8 hours, during which the water level declined only 5 feet. Thus the specific capacity of well 19 for this period of pumping was about $325 \mathrm{gpm}$ per foot of drawdown.

\section{Hydraulic Properties}

On December 8, 1964, an aquifer test was made by recording the drawdown of water level in well $18 \mathrm{H} 33$ caused by pumping $900 \mathrm{gpm}$ from well $18 \mathrm{H} 5$ located 700 feet to the south. Analysis of this data by the Theis (1935) nonequilibrium formula suggests that the transmissivity is about $1,600,000$ gallons per day per foot (gpd per ft) and the storage coefficient is about 0.002 (fig. 5). However, the water-level decline in the city of Adel well field (fig. 7) suggests that the average values in the area are much lower.

\section{Effects of Pumping}

The amount of interference by a pumped well with nearby wells that tap the same limestones as the municipal wells at Adel can be estimated using the graph in figure 6 . This granh shows the theoretical drawdown in water level caused by interference for wells spaced at distances of 10 feet to 1,000 feet apart for a continuous pumping period of 10 years at $1,000,5,000$, and $10,000 \mathrm{gpm}$. With intermittent pumping, the theoretical drawdown would be less than that shown in figure 6 .

\section{Declining Water Levels}

Water levels in a multiple-well field, such as at Adel, decline in a manner directly proportional to the rate at which the wells are pumped. Figure 7 is a graph that shows the decline in water level at the Adel Water Works located on the corner of West Third Street and North Maple Street near the center of the well field. Each measurement was made while the pumps were off and represents the approximate static water level at the time of measurement.

The water level declined at a rate of 0.08 foot per year from 1890 to $1940 ; 1.4$ feet per year during the World War II from 1940 to 1945; and 0.6 foot per year from 1945 to 1961 , it has been declining at a rate of 1.6 feet per year. Since 1890 it has declined a total of 28 feet.

Away from the center of pumpage the water level is relatively constant as shown by a graph (fig. 8) of the water level in the U.S.G.S. test well (18H16) in Adel. This well is located about 2,600 feet west of the city's Third Street well field.

\section{Quality of Water in Municipal Wells}

Water from the municipal wells at Adel is hard but otherwise of chemical quality suitable for most present uses. Its dissolved chemical constituents are below the U.S. Public Health Service (1962) recommended maximum concentrations for drinking water. It is suitable for most industrial use as well as for domestic and municipal uses. Chemical analyses of water from three of the municipal wells are given on table 4 . 


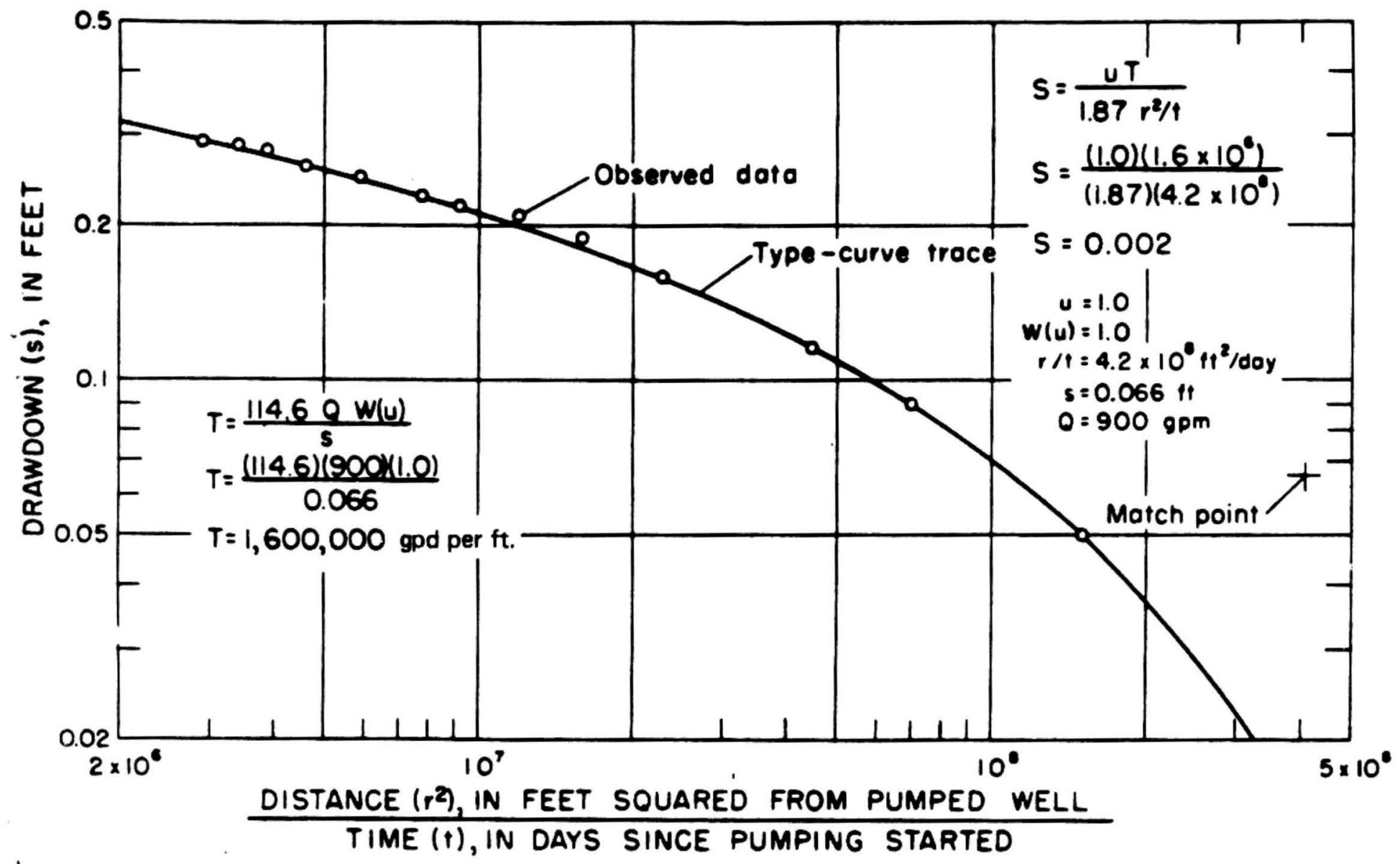

Figure 5. - Data plot for aquifer test of Suwannee Limestone at Adel.

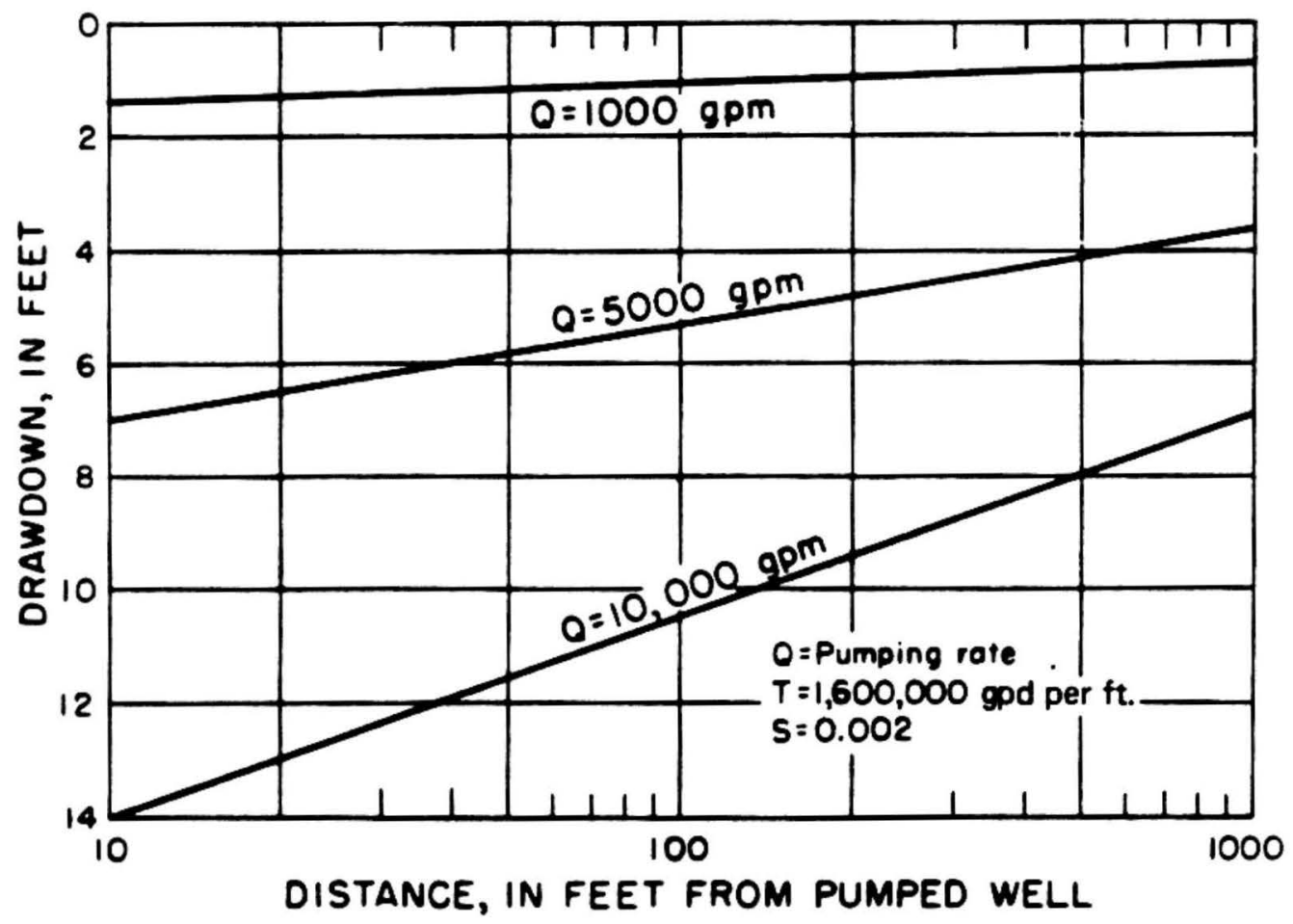

Figure 6. - Theoretical drawdown at Adel after 10 years continuous pumping. 
Table 4. - Chemical analyses of water from wells in Cook County, Ga.

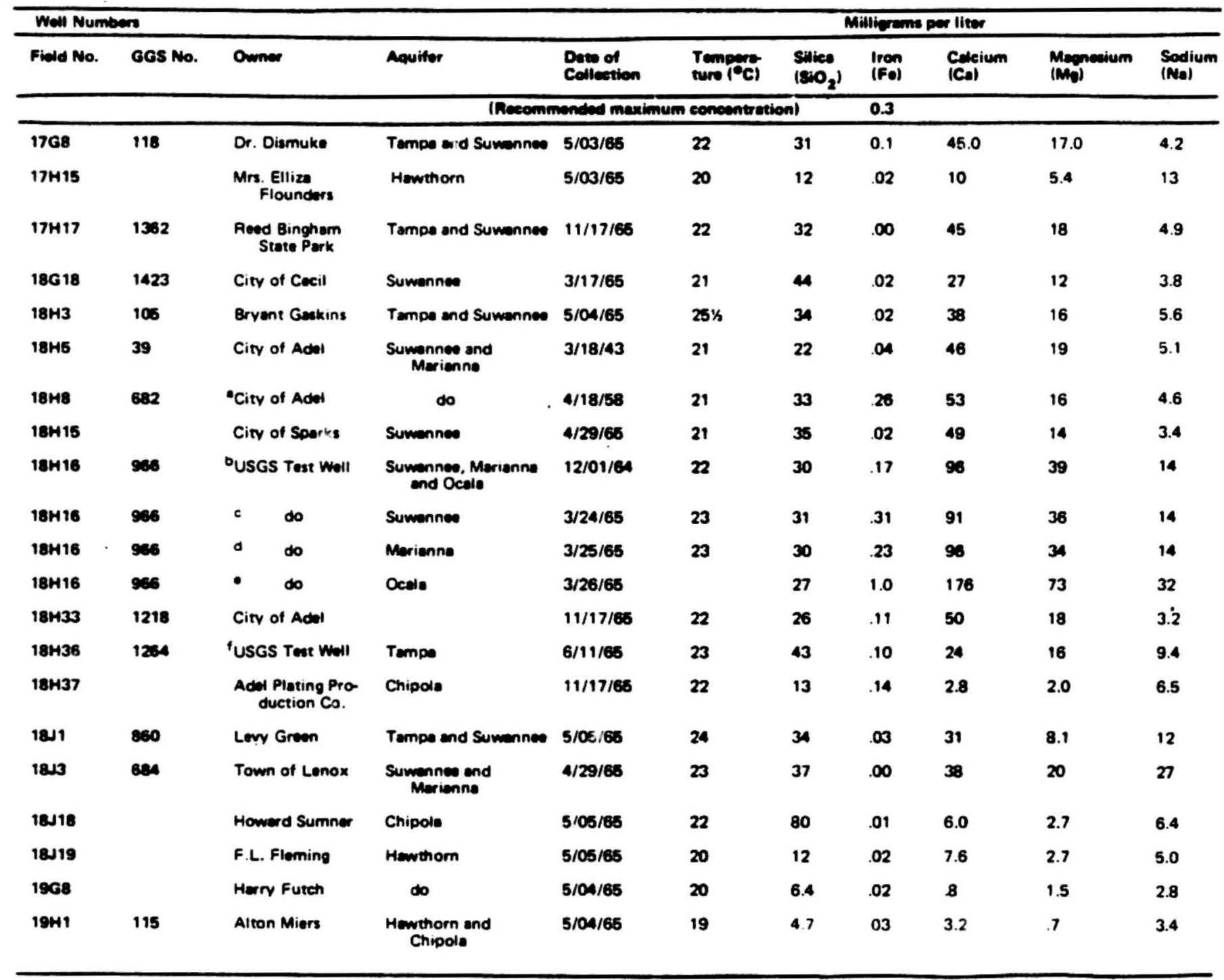

y Analyzed by U. S. Geological Survey.

2/ Recommended maximum concentration for area covered by this report (average maximum daily air

-From Wait, 1980, p. 43

bInt. from $207-869 \mathrm{ft}$.

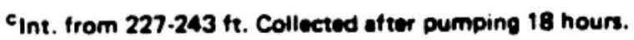

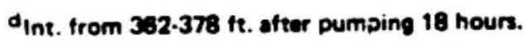

Int. from $452468 \mathrm{ft}$. after 10 hours pumping.

'Collected after pumping 20 hours. 


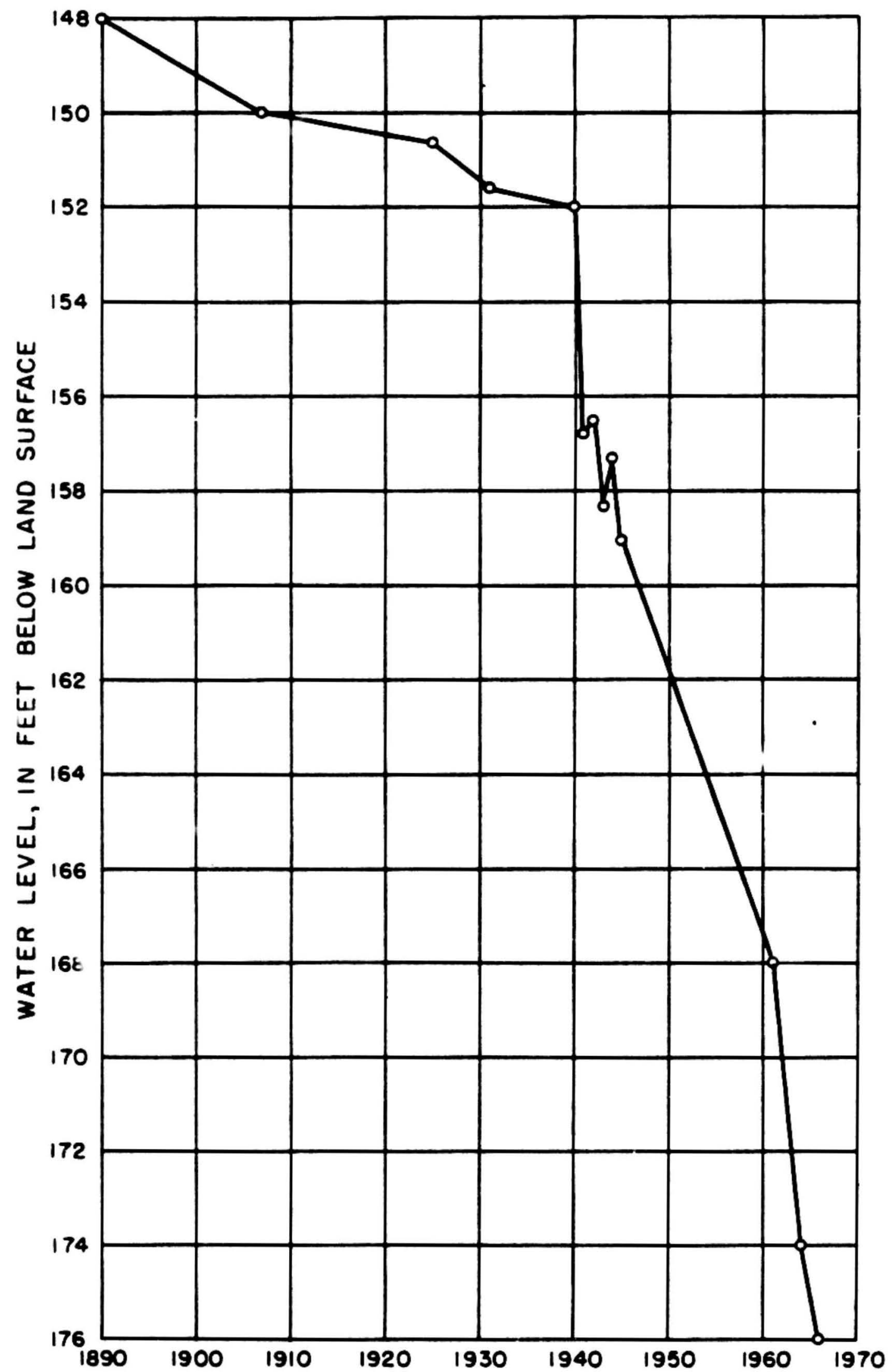

Figure 7. - Water-level decline in Adel at Third Street well field, 1892-1966. 


\section{City of Cecil}

In March 1965, the city of Cecil drilled its first municipal well, 18G18, at the southeast corner of Union and Rountree Streets (fig. 9). The well was drilled by Everett Drilling Company to a depth of 308 feet and cased to a depth of 214 feet with 8-inch steel casing.

Samples of the rocks penetrated by the well were collected by the driller and examined by the author. Description of these samples are given below:

Description

MIOCENE SERIES (Undifferentiated)

Sand: mottled grayish-pink (5R8/2) to light red

$(5 R 6 / 6)$, fine to very coarse-grained, subangular

to subrounded, poorly sorted, argillaceous ....

Sand: pale yellowish orange (10YR8/6), fine to coarse-grained, subangular, poorly sorted, argillaceous. . . . . . . . . . . . . . . . . . .

Chert and sandy clay: mottled white (N9) to grayish orange $(10 Y R 7 / 4) \ldots \ldots \ldots \ldots$

Sand: pale yellowish orange (10YR8/6), fine-grained, subangular, well sorted, argillaceous ...........

Sand: very pale orange (10YR8/2), fine-grained, subangular, well sorted, argillaceous, calcareous . . . .

TAMPA FORMATION

Limestone: yellowish-gray (5Y8/1), sandy, firmly cemented

No samples . . . . . . . . . . . . . . . . .

Limestone: white (N9), fossiliferous, weakly cemented

Limestone: pale yellowish brown (10YR6/2), sandy, dolomitic, firmly cemented, dense

\section{UNCONFORMITY}

OLIGOCENE SERIES

SUWANNEE LIMESTONE

Limestone: white (N9), fossiliferous, firmly cemented. .
Thickness

(feet)

Depth

(feet)

\section{0}

20

40

60

5

65

75

140

25

165

5

170

175

180

45

225

70

\section{5}

During construction of this well, electric resistivity and self-potential logs were made of the upper part of the well before the casing was installed. After completion, these two types of logs were made of the lower part of the well, and gamma-radiation and well diameter logs were made of the entire well. These logs show that this well taps the Suwannee Limestone (fig. 10).

\section{Hydraulic Properties}

On March 15 and 16,1965, an aquifer performance test was made by measuring the drawdown of water level in well $18 \mathrm{G} 18$ caused by pumping the well at $53 \mathrm{gpm}$. The data were analyzed using the method developed by Ferris and others (1962). The transmissivity of the Suwannee Limestone at Cecil is estimated to be about 50,000 gpd per foot (fig. 11). The storage coefficient could not be determined.

\section{Quality of Water}

Water from the municipal well at Cecil contains dissolved mineral concentrations that are well below the U.S. Public Health Service recommended maximum limits for drinking water. A sample of the water was analyzed by the U.S. Geological Survey in 1965. This analysis, which is given in table 4 , shows the water to be moderately hard and suitable for munici$\mathrm{pal}$, most industrial, and irrigation uses.

\section{City of Lenox}

The city wells of Lenox produce from the principal artesian aquifer. A well drilled in 1946 by Layne-Atlantic Company produces water from limestone of Oligocene age. Another 


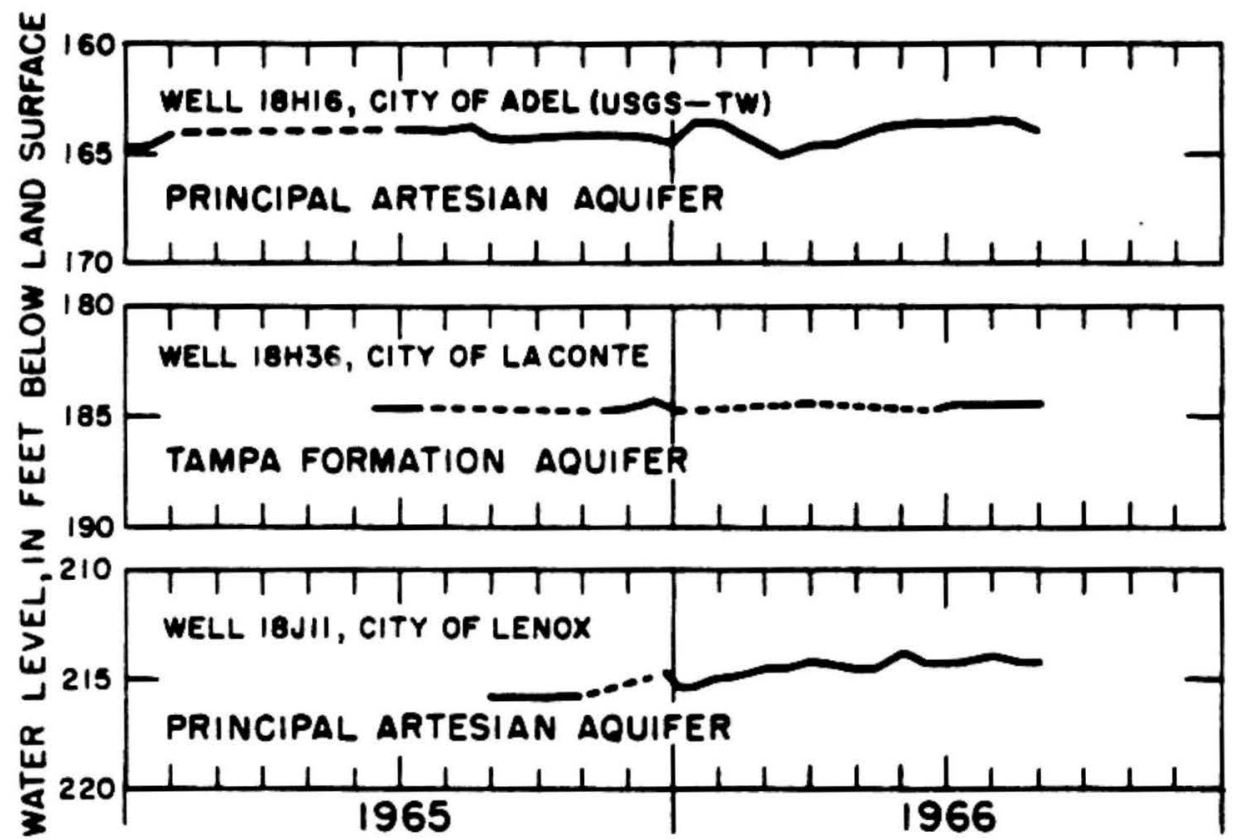

Figure 8. - Hydrographs of water levels in three Cook County wells during 1965-66.

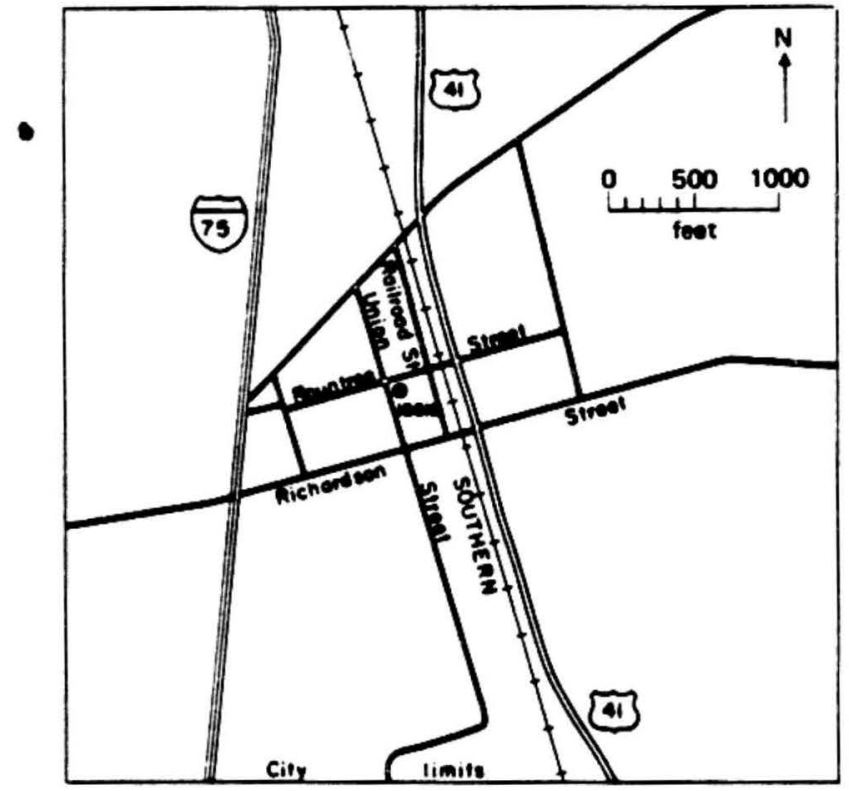

Figure 9. - Well location at Cecil. 


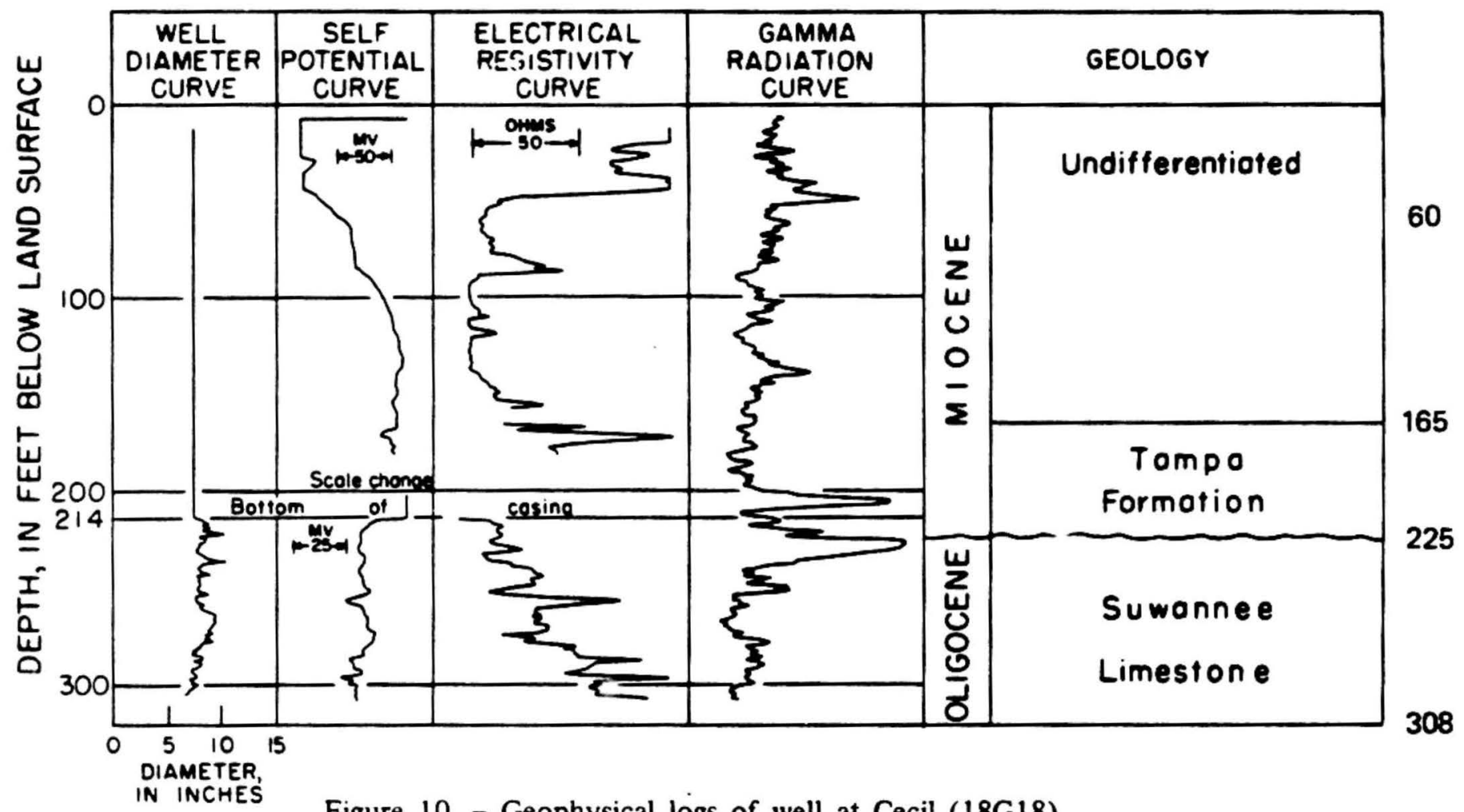

Figure 10. - Geophysical logs of well at Cecil (18G18).

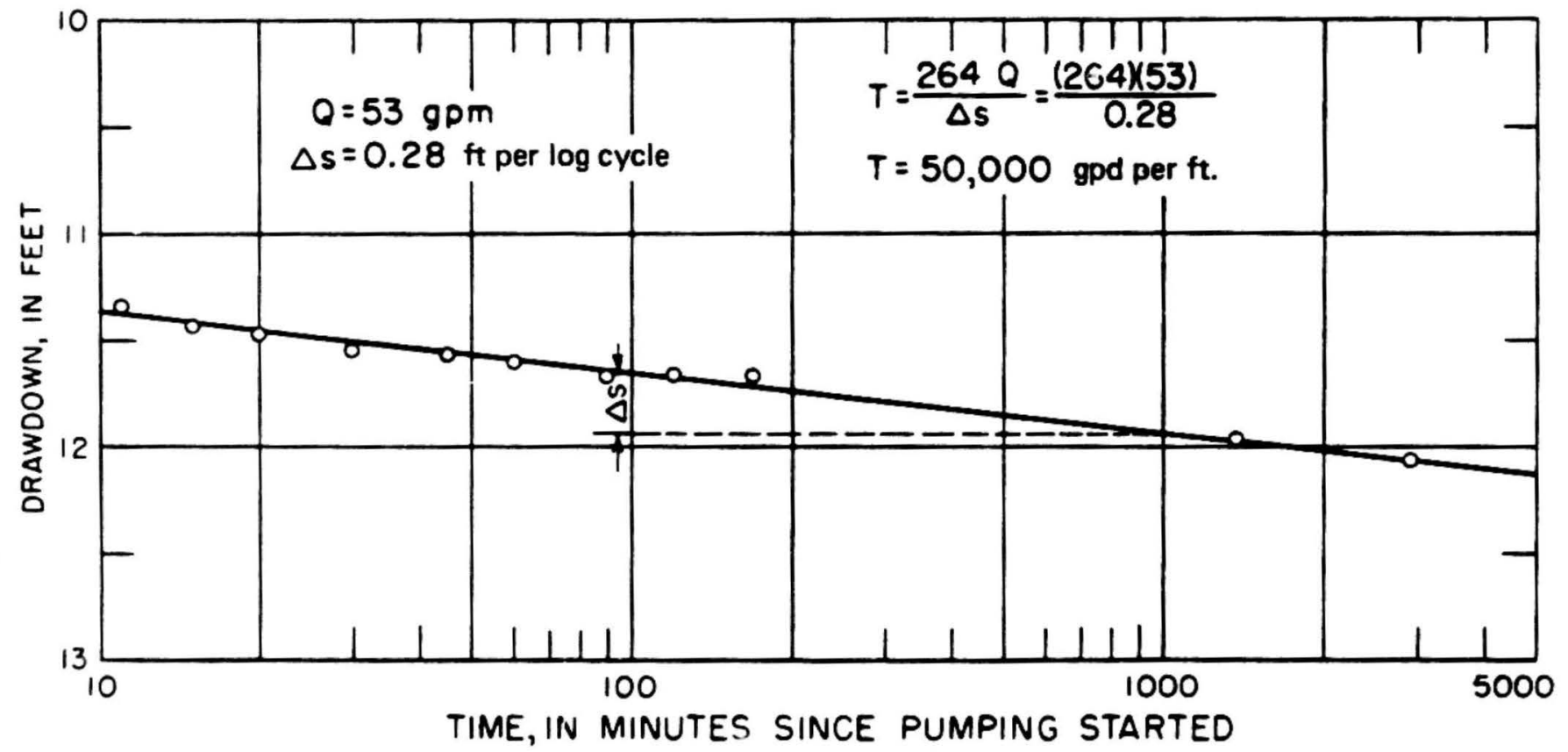

Figure 11. - Data plot for aquifer test of Suwannee Limestone at Cecil. 
well drilled in 1957 by M. M. Gray Well Company produces from limestones of Oligocene and late Eocene age. Cuttings from this well were studied by S. M. Herrick, who prepared the following log:

\section{Description}

$\begin{array}{ll}\text { Thickness } & \text { Depth } \\ \text { (feet) } & \text { (feet) }\end{array}$

MIOCENE SERIES (Undifferentiated)

Clay: mottled, sandy, limonitic

Clay: as above, with some interbedded limestone; gray to white, much calcitized, dense, sandy . . . . .

Clay: pale brownish-gray, somewhat laminated, sandy, with some interbedded limestone; white sandy. . .

Lithology as above, with scattered tongues of dolomitic rock; light brown, saccharoidal

Dolomitic rock; light brown, saccharoidal, somewhat fossiliferous, with impressions and molds of molluscan shells

OLIGOCENE SERIES (Undifferentiated)

Limestone: cream to light-brown, somewhat dolomitized, nodular, fossiliferous at certain levels, with some Foraminifera . . . . . . . . . . . . . . . Pararotalia mexicana var., Quinqueloculina sp. at 260-270 feet Dictyoconus sp. at $410-420$ feet

\section{OCALA LIMESTONE}

Limestone: as above, but becoming white and chalkier at depth.

Lepidocyclina ocalana, Lepidocyclina sp. at 490-500 feet Planulina kendrickensis, Asterocyclina nassauensis at $490-500$ feet

\section{Potentiometric Surface}

The potentiometric surface shown in figure 1 is an imaginary surface representing the static water level (in feet above mean sea level) in wells tapping the principal artesian aquifer as measured in April 1966. It is useful in showing the general direction of ground-water flow in the aquifer system and in showing areas of recharge and discharge. Ground water flows from areas of high potentiometric elevations toward areas of low potentiometric elevations in a direction generally normal to each contour. The general directions of groundwater flow in the upper part of the principal artesian aquifer in Cook County are shown by arrows in figure 1 .

High potentiometric elevations in southern and western Cook County suggest that appreciable rainfall percolates through the Miocene sands and clays to recharge the aquifer in these areas. The high potentiometric contours and steep gradient in northem Cook County indicate that water is moving into northern Cook County from a recharge area located to the northwest of the county.

Data are inadequate to construct a potentiometric map of the limestone aquifer in the Tampa Formation. However, water levels in the Tampa in Cook County are about the same as those in the upper part of the principal artesian aquifer system shown in figure 1.

\section{Quality of Water}

Samples of water from at least one well in each town and from numerous other wells that tap the Suwannee and Marianna Limestones were analyzed. In each well the water was hard, but of quality suitable for municipal, domestic, and most industrial uses. Chemical analyses of these water samples are given in table 4 .

Water in the Ocala Limestone is highly mineralized and of poor quality. 


\section{HYDROGEOLOGY OF THE TAMPA FORMATION AQUIFER}

Many wells in southern Cook County tap both the Tampa Formation and the Suwannee Limestone, but generally the Tampa is cased out. However, in northern Cook County where the Suwannee is deepest, many wells tap only the Tampa.

The upper surface of the Tampa is ver irregular in Cook County. As shown in figure 12, the top ranges from 100 feet above mean sea level in southern Cook County to below sea level in northern Cook County.

\section{U. S. Geological Survey Test Well at Laconte}

In June 1965 the U.S. Geological Survey, as part of this cooperative project, drilled a test well (GGS 1264 and 18H36) at Laconte to determine the amount and quality of water available from the Tampa Formation. Samples of the rocks penetrated by the well were collected by the driller and later examined and described by the author. Descriptions of these samples are given below:

\section{Description}

$\begin{array}{ll}\text { Thickness } & \text { Depth } \\ \text { (feet) } & \text { (feet) }\end{array}$

MIOCENE SERIES (Undifferentiated)

Clay: mottled to grayish orange (10YR7/4), sandy,

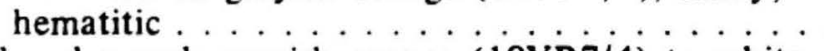

Sand and gravel: grayish orange $(10 Y R 7 / 4)$ to white (N9), medium-grained sand to fine pebble gravel, subangular, poorly sorted; stained quartz . . . . . .

Sand: mottled grayish orange pink $(10 \mathrm{R} 8 / 2)$ to very dark red $(5 \mathrm{R} 2 / 6)$, medium grained, subangular, fairly well sorted; argillaceous hematitic ...... .

Sand: yellowish gray $(5 Y 8 / 1)$, fine grained, subangular, argillaceous, well sorted, clear quartz; calcareous fragments common; phosphatic ........

Sandstone: yellowish gray (5Y8/1), fine to medium grained, subangular, well sorted, clear quartz; firm to weak calcareous cement .........

Sandstone: yellowish gray $(5 Y 8 / 1)$, fine to medium grained, subangular, well sorted, clear quartz; weak argillaceous cement ............44 43 fossils sparse, sandy

$\begin{array}{ll}20 & 105 \\ 10 & 115 \\ 43 & 158\end{array}$

182 (total depth)

The well was drilled to a depth of 210 feet and cased to a depth of 198 feet, with 4inch steel casing. Upon completion of the test well, the author made electric-resistivity, selfpotential and gamma-radiation logs of the well. The well casing is seated on the Tampa Formation and all of the water pumped came from a thin permeable bed at a depth of about 195 feet. The static water level was about 185 feet below land surface or about 10 feet above the water-bearing bed. This water level was measured periodically during the study. and it remained nearly constant as shown by the graph in figure 8 .

\section{Hydraulic Properties of the Tampa Formation}

On June 10, 1965 a 5 hp submersible test pump was installed. After pumping for only a few minutes at $50 \mathrm{gpm}$, the pump broke suction. The pumping rate was reduced by valves until the pump regained suction and pumped no air. The metered discharge showed that the pump supplied $21.6 \mathrm{gpm}$ continuously for about 20 hours without again breaking suction. This means that the specific capacity of the well is about $2.2 \mathrm{gpm}$ per feet for this period of pumping, an that the maximum yield of the aquifer at Laconte is about $22 \mathrm{gpm}$. 


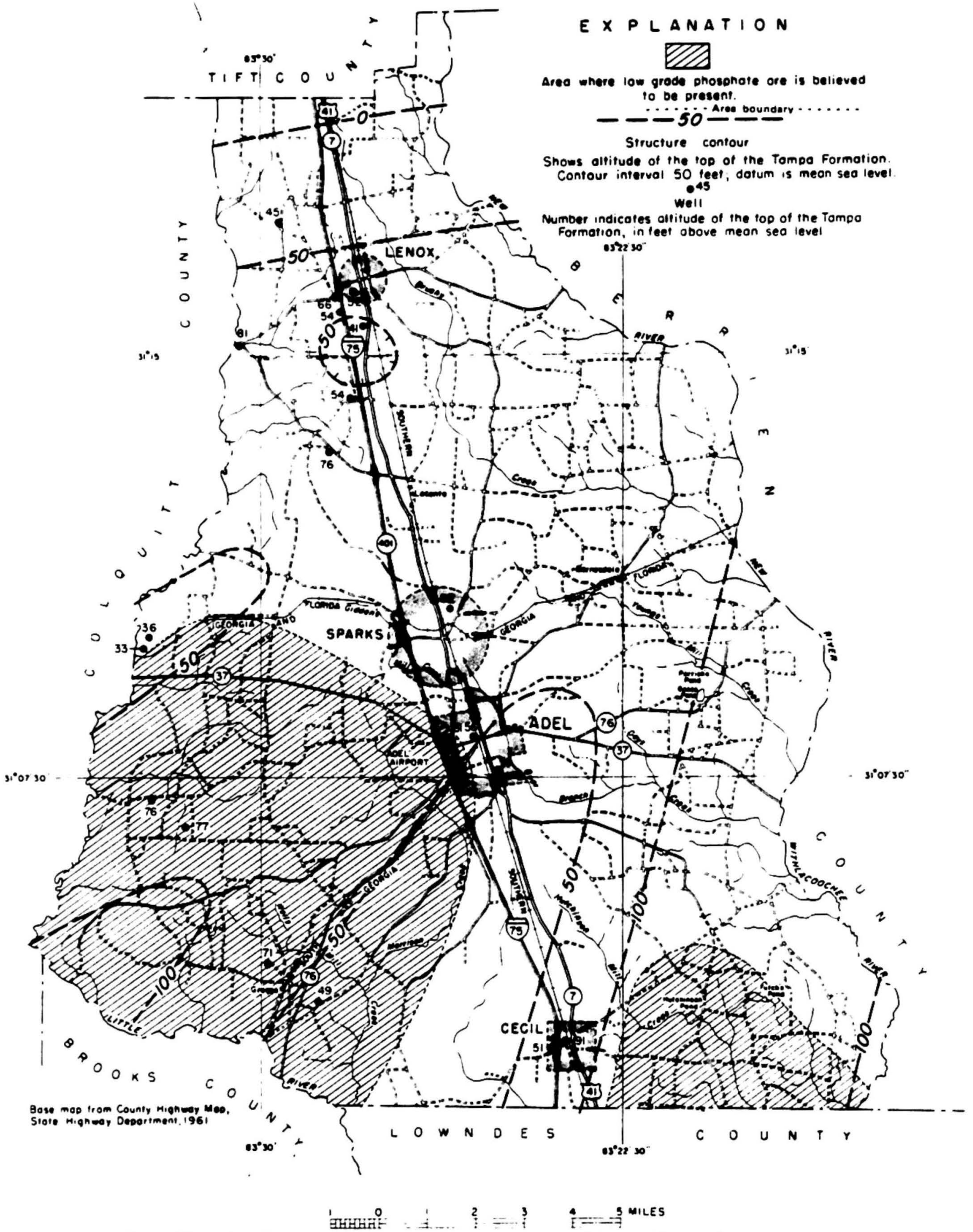

Figure 12. - Map showing configuration of the top of the Tampa Formation and location of low grade phosphate deposits. 
Water-level recovery data from the pumping test were analyzed by the straight-line graphical method (Cooper and Jacobs, 1946), which is a modified form of the Theis (1935) nonequilibrium formula. The transmissivity was determined to be about $17.000 \mathrm{gpd}$ per ft (fig. 13). The storage coefficient was not determined.

The maximum yield of wells that tap the Tampa Formation in Cook County south of Lenox generally is about 10 to 20 gallon per minute. Their maximum yield increases northward from Lenox until, near Tift County, the maximum yield in some wells is as much as $150 \mathrm{gpm}$.

\section{Quality of Water}

Ground water in the Tampa Formation at Laconte is moderately hard to hard and suitable for domestic, most industrial and irrigation uses. A chemical analysis of water from well $18 \mathrm{H} 36$ is given in table 4.

\section{VOLUME OF GROUND-WATER FLOW}

The potentiometric map of the Suwannee Limestone provides a means whereby the volume per day of giound-water flow through Cook County can be estimated. The formula used in this comparison is $Q=T I L$, where

$\mathrm{Q}=$ Volume of flow in gallons per day.

$T=$ Transmissivity of the aquifer.

1 = Hydraulic gradient in feet per mile (from fig. 1).

$\mathrm{L}=$ Distance along a given contour in miles (from fig. 1 ).

To determine the transmissivity of the Suwannee and Marianna Limestone, eight aquifer tests were conducted during this study on wells in Cook County which tap the Suwannee and Marianna. Results of these tests suggest that the average transmissivity in Cook County for these two limestones is about $200,000 \mathrm{gpd}$ per $\mathrm{ft}$. As computed, the approximate volume of ground-water flow in the Suwannee and Marianna Limestones in Cook County is as follows:

- Amount of water flowing south across 90-foot contour in northern Cook County (see fig. 1) .............

- Amount of water flowing north across 85-foot contour in southern Cook County ................. 5,000,000 gpd

- Amount of water recharging aquifer and flowing across

80 -foot contour in western Cook County. . . . . . . 7,000,000 gpd

- Approximate total volume of water flow . . . . . . . . 18,000.000 gpd

Using a transmissivity of 17,000 gpd per $\mathrm{ft}$ (page 79), the potentiometric map shown in figure 1 (the water levels in the Tampa Formation are about the same as those in the Suwannee Limestone), and the formula $Q=T \perp \mathbf{L}$, the volume of ground-water flow in the Tampa Formation was computed to be:

- Amount of water flowing south across the 90-foot contour in northern Cook County (fig. 1) . . . . . . 510,000 gpd

- Amount of water flowing north across 85-foot contour in southern Cook County .......... 425,000 gpd

- Amount of water recharging aquifer and flowing across 80 -foot contour in western Cook County. . . . . . . 595,000 gpd

- Total volume of water flow . . . . . . . . . . 1,530,000 gpd

Data on wells in Cook County gathered during the investigation are tabulated in table 5 . 
Table 5. - Record of Wells in Cook County, Ga.

\begin{tabular}{|c|c|c|c|c|c|c|c|c|c|c|c|c|}
\hline \multirow{2}{*}{$\begin{array}{l}\text { Moll } \\
\text { No. }\end{array}$} & \multirow[t]{2}{*}{ Owner or Mame } & \multirow[t]{2}{*}{ Driller } & \multirow{2}{*}{$\begin{array}{l}\text { Dete } \\
\text { comploted }\end{array}$} & \multirow{2}{*}{ 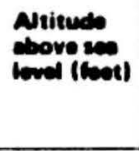 } & \multirow[t]{2}{*}{ Type of Well } & \multirow{2}{*}{$\begin{array}{l}\text { Depeth of } \\
\text { Wiell (feen) }\end{array}$} & \multirow{2}{*}{$\begin{array}{l}\text { Diemorew of } \\
\text { Well linehrent }\end{array}$} & \multirow{2}{*}{$\mid \begin{array}{l}\text { Depoth to } \\
\text { which well } \\
\text { it canced (fent) }\end{array}$} & \multicolumn{2}{|c|}{ Waler Leal } & \multirow{2}{*}{ Wen of $_{\text {Woter }}$} & \multirow{2}{*}{ Rementes and OCS Mo. } \\
\hline & & & & & & & & & 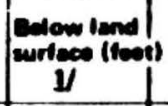 & $\begin{array}{l}\text { Date of } \\
\text { meenurement }\end{array}$ & & \\
\hline 1768 & D.F. Burton & W.B. Graham & $2 / 11 / 46$ & 225.7 & Drilled & 330 & 4.5 & 176.0 & 147.14 & $4 / 18 / 66$ & Domestic & $\begin{array}{l}\text { Curtinges collected } \\
\text { GGS1 } 18\end{array}$ \\
\hline 1769 & R.M. Alderman & Devis Drl. Co. & $11 / 14 / 62$ & 232.2 & do & 240 & 4 & 163.7 & 152.36 & $4 / 18 / 66$ & do & \\
\hline 17610 & Frank Gibbs & Bishop DrI.Co. & -.- & 220.6 & do & $\cdots$ & 4 & $\cdots$ & 141.58 & $4 / 18 / 66$ & do & \\
\hline 17611 & USGS A.H. 4 & U.S.G.S. & $121-/ 63$ & 171 & Bored & $\cdots$ & 4 & $\ldots$ & $\ldots .$. & $\ldots .$. & & $\begin{array}{l}\text { Cuttinge collected. } \\
\text { filled in } \\
\text { GGS1200 }\end{array}$ \\
\hline 17612 & Earnest Flowers & Bishop Dri.Co. & $3 / 03 / 66$ & $\cdots-$. & Drilled & 234 & 4 & 197 & 147(A) & $3103 / 66$ & Domestic & $\begin{array}{l}\text { Curtine collected } \\
\text { GGS1606 }\end{array}$ \\
\hline 17613 & Co5 Ga. Tech & Ga. Tech & $7 / \cdot / 66$ & $\cdots$ & $\begin{array}{l}\text { Cored } \\
\text { Drilled }\end{array}$ & 96 & 4 & -- & ...- & $\cdots$ & & $\begin{array}{l}\text { Drilled as tew hole- } \\
\text { filled in-Cutting } \\
\text { collected } \\
\text { GGS1658 }\end{array}$ \\
\hline 17H2 & Bill Purvis & Bishop Dil.Co. & 1960 & 233.7 & Bored & 65 & 12 & - & $\cdots .$. & $\cdots$ & & Gernme-roy los \\
\hline i7ma & M.H. Berryhill & & 1864 & 252.7 & Drilled & 360 & 4 & - & 171.85 & $4 / 19 / 66$ & Domestic & \\
\hline 17146 & J.T. Roundtree & Rown Brothers & 1968 & 262.7 & do & 278 & 4 & $\ldots$ & 179.54 & -- & $\infty$ & \\
\hline $17 \mathrm{H6}$ & Mrs. Noll Purvis & $\infty$ & 1960 & 223.0 & do & 287 & 4 & $\ldots$ & $\cdots$ & -- & do & $\begin{array}{l}\text { Could not maseure } \\
\text { neter level }\end{array}$ \\
\hline 17H7 & John Flounders & Friedlsonder & 1960 & 247.6 & do & 360 & 4 & 120 & 162.82 & $4 / 19 / 66$ & do & \\
\hline 1748 & Bill Purvis & Bishop Dil.Co. & 1963 & 232.6 & do & 263 & 4 & 225 & 153.79 & $4 / 19 / 66$ & do & \\
\hline 17H9 & USGS A.H. 9 & U.s.G.S. & $12 / \cdots / 63$ & 255.1 & Bored & • & 4 & $\ldots .$. & $\cdots$ & $-\cdots$ & & $\begin{array}{l}\text { Curting collected. } \\
\text { filled in } \\
\text { GGS1201 }\end{array}$ \\
\hline $17 H 10$ & doA.H. 10 & do & $121-/ 63$ & $\ldots .$. & do & 36 & 4 & $\cdots \cdot \cdot$ & $\cdots \cdot$ & $\cdots$ & & GGS1202 \\
\hline $17 H 13$ & USGS T.W. 1 & Tyson Dean & $21 \cdots / 65$ & $\ldots .$. & Drilled & 140 & 4 & $\cdots \cdot$ & $\ldots .$. & $\cdots$ & & $\begin{array}{l}\text { Curtings collected- } \\
\text { Electric and Germme } \\
\text { ray loos } \\
\text { GGS1422 }\end{array}$ \\
\hline $17 H 15$ & Elliza Flounder & & $\cdots-$ & $\cdots$ & Bored & 54 & 12 & $\cdots \cdot$ & 28.0 & $1 / 9 / 65$ & & Gemmeray log \\
\hline $17 H 17$ & $\begin{array}{l}\text { Roed Bingham no.1 } \\
\text { State Park }\end{array}$ & Creasy Drl.Co. & $8 / \cdot-/ 65$ & 213.2 & Drilled & 230 & 4 & 192 & 135 & $9 / \cdot / 65$ & $\begin{array}{l}\text { Public } \\
\text { Supply }\end{array}$ & $\begin{array}{l}\text { Cutting collected-Elec. } \\
\text { tric and Gemma-ray } \\
\text { logs GGS1362 }\end{array}$ \\
\hline $17 H 19$ & $\begin{array}{l}\text { Reed Bingham no.3 } \\
\text { State Park }\end{array}$ & do & $11 / \cdot / 65$ & 216.2 & do & $\cdots$ & 4 & $\ldots$. & 137.57 & $4 / 19 / 66$ & do & $\begin{array}{l}\text { Culting collected } \\
\text { GGS1470 }\end{array}$ \\
\hline
\end{tabular}




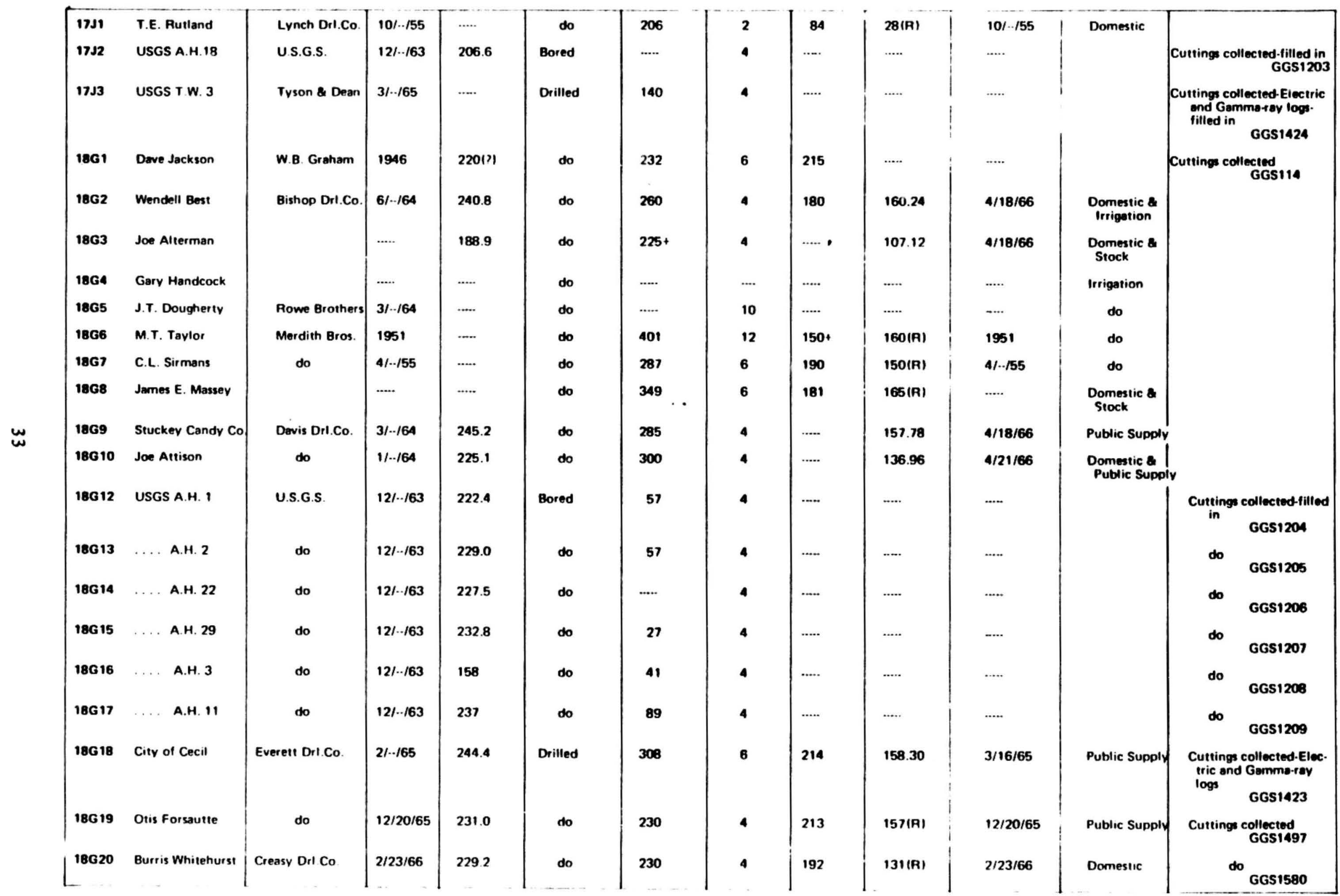




\begin{tabular}{|c|c|c|c|c|c|c|c|c|c|c|c|c|}
\hline 18621 & Gredy Whitehurst & do & $2 / 24 / 66$ & 229.2 & do & 296 & 4 & 190 & 136.25 & $4 / 18 / 66$ & & do GGS1681 \\
\hline 18622 & $\begin{array}{l}\text { Mont.Phos. Co. IHol } \\
\text { No.25) }\end{array}$ & do & 1866 & 240.0 & do & 106 & 4 & ..... & $\cdots \cdot$. & $\cdots \cdots$ & & $\begin{array}{l}\text { Cultings colleciod-filled } \\
\text { in } \\
\text { GGS1587 }\end{array}$ \\
\hline 18623 & Burris Whitehurst & Rowe Brothers & 1964 & 220.7 & $\infty$ & 290 & 4 & 240 & 134.34 & $4 / 21 / 66$ & Irrigetion & \\
\hline 18624 & $\begin{array}{l}\text { Flotcher's Foedor } \\
\text { Lot }\end{array}$ & Evorott Dri.co. & $5 /-166$ & $\cdots$ & do & 180 & 4 & 95 & 117 (ค) & 5. . . /66 & Stock & 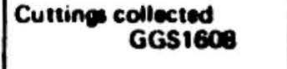 \\
\hline 18025 & City of Cocil no.2 & do & 1966 & $\cdots$ & do & 230 & 4 & $\cdots$ & -.- & $\cdots$ & Public Supply & ${ }^{d}$ GGS1663 \\
\hline 1EHI & City of Adel & Layno-Autentic & 1943 & 239.4 & do & 376 & 12 & 211 & $\cdots$. & $\cdots$ & & Well abendoned \\
\hline $18 \mathrm{~Hz}$ & City of Adel no.5 & do & 1946 & 238.1 & do & 396 & 12 & 231 & 159.51 & $4 / 22 / 66$ & Public Supply & $\begin{array}{l}\text { Curtines collected } \\
\text { GGS122 }\end{array}$ \\
\hline $18 \mathrm{HH}$ & Bryent Gemkins & Grehiman \& Risher & $1 / 30 / 46$ & 274.8 & do & 291 & 4 & 202 & 197.86 & 4/20/66 & Domestic & do GGS105 \\
\hline $18 m 4$ & City of Adal & Gray Drl.Co. & 1931 & 240.8 & do & 366 & 10 & 171 & ..... & $\cdots \cdot \cdot$ & & Wall abendonod \\
\hline 1046 & do & Layno-Atientic & 1940 & 240.8 & do & 376 & 12 & 211 & 172.57 & $4 / 22 / 66$ & & $\begin{array}{l}\text { Cuttinge collected } \\
\text { GGS30 }\end{array}$ \\
\hline $18 \mathrm{He}$ & do & $\cdots$ & 1926 & - & do & 325 & 10 & $\cdots$ & $\cdots$ & $\cdots \cdot \cdot$ & & Well sbendoned \\
\hline $18+48$ & do & Loyne-Atlantic & 1957 & 230.1 & do & 369 & 16-12 & 253 & 150.16 & 4/22/66 & Public Supply & 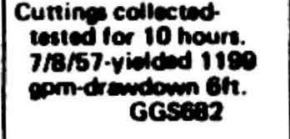 \\
\hline 1849 & do & -... & 1893 & $\cdots$ & do & 220 & 4.5 & $\cdots$ & $154(R)$ & ... & & $\begin{array}{l}\text { See Ge.Geol.Survery } \\
\text { Bull.15,p.53 }\end{array}$ \\
\hline 18 1ен10 & Ralph Lendrey & W.B. Groham & - & 277.0 & do & 100 & 6 & 60 & $65(A)$ & -- & Domestic & $\begin{array}{l}\text { Cuttinge collected } \\
\text { GGS116 }\end{array}$ \\
\hline 18H11 & J.W. Carson & $\cdots$ & 1944 & .... & Bored & 46 & 12 & $\cdots$ & $\cdots$ & $\cdots \cdots$ & & Gemmo-roy los \\
\hline $16 \mathrm{H12}$ & Willie McCrene & $\cdots \cdot-$ & 1960 & $\cdots$ & $\infty$ & 43 & 12 &.- & $\cdots .$. & $\cdots \cdot$. & & Gemmorev log \\
\hline $18 \mathrm{H} 13$ & City of Adel & Layno-Atlantic & $3 / . / 61$ & 239.6 & Drilled & 369 & 16 & 253 & 163.2 & $4 / 22 / 66$ & Pubtic Supply & 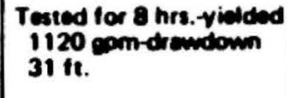 \\
\hline $18 \mathrm{H} 14$ & do & White \&o. & 1907 & 240.5 & do & 675 & 10 & $60(?)$ & $150.9(R)$ & $8 / 28 / 42$ & & $\begin{array}{l}\text { Sae Woter-Supply Peper } \\
341,0.145\end{array}$ \\
\hline $18 \mathrm{H} 15$ & City of Sparks & ..... & 1908 & 236.3 & do & 407 & 8 & $350+$ & 157.50 & $4 / 20 / 66$ & & do \\
\hline $18 \mathrm{H} 16$ & USGS Test Well & Carr Dri.Co. & 1964 & 241.4 & do & 865 & 8 & 207 & 164.16 & $4 / 20 / 66$ & Observation & $\begin{array}{l}\text { Cuttings collected.Elec. } \\
\text { and germmo-roy logs. } \\
\text { caliper log. Flowmetior } \\
\text { test, Recorder on woll } \\
\text { GGS966 }\end{array}$ \\
\hline 18н17 & Dan Gray & Merdity Bros. & 1955 & $\cdots \cdot$ & do & $510+$ & 8 & 110 & 2101R) & 1955 & $\begin{array}{l}\text { Irrigstion,Dom. } \\
\text { \& Stock }\end{array}$ & \\
\hline
\end{tabular}




\begin{tabular}{|c|c|c|c|c|c|c|c|c|c|c|c|c|}
\hline 18H10 & E.J. Betts & Steven Southern & 1955 & $\ldots .$. & do & 440 & 6 & 250 & GO|R| & 1955 & $\begin{array}{l}\text { Irrigation } 8 \\
\text { Stock }\end{array}$ & \\
\hline 18H19 & G.C. Henry & Bishop Drl.Co. & 1956 & 257.1 & do & 394 & 4 & 150 & 177.50 & $4 / 20 / 66$ & $\begin{array}{l}\text { Domestic } 8 \\
\text { Stock }\end{array}$ & \\
\hline $18 H 20$ & Mrs. E. Mathis & Stewart Brothers & $5 / . . / 64$ & & do & 210 & & 84 & 135(R) & $5 / . . / 64$ & do & \\
\hline 18н21 & L.D. Daugherty & Bishop Drl.Co. & $\ldots .$. & 216.9 & do & 300 & 4 & ..... & 182.75 & $4 / 20 / 66$ & do & \\
\hline 18н22 & Steve Summer & $\cdots$. & 1959 & $\cdots+$. & do & $\ldots+.$. & 6 & $\ldots .$. & $\ldots .$. & $\ldots \cdots$ & $\begin{array}{l}\text { Irrigation. } \\
\text { Dom.\&Stock }\end{array}$ & \\
\hline Ian23 & City of Sparks & Layne-Atlantic & $4 / . . / 48$ & 232.5 & do & 497 & 8 & 394 & 157.30 & $4 / 20 / 66$ & Public Supply & \\
\hline 18н24 & $\begin{array}{l}\text { State of Georgie } \\
\text { I.75 Rest Sta. }\end{array}$ & Merrell Gray & $6 / 29 / 60$ & 271.5 & do & 302 & 6 & 224 & 186.09 & $4 / 19 / 66$ & do & $\begin{array}{l}\text { Cuttings collected } \\
\text { GGS629 }\end{array}$ \\
\hline 18425 & USGS A.H. 8 & U.S.G.S. & $121 \cdot-/ 63$ & 236.7 & Bored & 107 & 4 & $\cdots .$. & $\ldots \ldots$ & $\ldots .$. & & $\begin{array}{l}\text { Curtings collected. } \\
\text { filled in } \\
\text { GGS1210 }\end{array}$ \\
\hline 18н26 & … A.H. 26 & do & $12 / \cdot . / 63$ & 246.2 & do & 22 & 4 & $\ldots .$. & ..... & .... & & do GGS1211 \\
\hline 18427 & W A.H. 20 & do & $12 / \cdot . / 63$ & 255.0 & vo & 107 & 4 & $\ldots .$. & ..... & $\ldots .$. & & do GGS1212 \\
\hline $18 \mathrm{H} 28$ & ... A.H. 12 & do & $12 / . . / 63$ & 238.0 & to & 84 & 4 & $\cdots$ & ..... & $\ldots .$. & & do GGS1213 \\
\hline 18н29 & W. A.H. 25 & do & $121 \cdot-.63$ & 250.0 & do & 17 & 4 & $\ldots$ & $\ldots .$. & $\ldots .$. & & do GGS1214 \\
\hline $18 \mathrm{H30}$ & W.A.H. 13 & do & $12 / \cdot-/ 63$ & 262.8 & do & 88 & 4 & $\cdots$ & $\ldots$ & $\cdots$ & & do GGS1215 \\
\hline 18н31 & W. A.H. $\mathbf{2 3}$ & do & $121--63$ & 260.5 & do & 17 & 4 & $\ldots$ & $\ldots .$. & $\ldots .$. & & do GGS1216 \\
\hline $18 \mathrm{H} 32$ & A.A.H. 24 & do & $121 \cdot \cdot / 63$ & 261.2 & do & 17 & 4 & $\ldots .$. & ..... & $\ldots .$. & & do GGS1217 \\
\hline $18 \mathrm{H} 33$ & City of Adel & Layne-Atlantic & $10 / \cdot-/ 64$ & 240.1 & Drilled & 393 & 18 & 207 & 162.60 & $4 / 22 / 66$ & Public Supply & $\begin{array}{l}\text { Cuttings collected-Elec- } \\
\text { tric and gemme-roy } \\
\text { logs-OW andvsis 11/ } \\
17 / 65 \text { GGS1218 }\end{array}$ \\
\hline $18 \mathrm{HA4}$ & W.C. Patterson & Bishop Dri.Co. & 1956 & 242.0 & do & $\cdots .$. & 4 & $\ldots .$. & 164.36 & $4 / 20 / 66$ & Domestic & $\cdot$ \\
\hline 18436 & USGS TW. 2 & Creasy Drt.Co. & $6 /--/ 65$ & 2638 & do & 210 & 4 & 189 & 184.64 & $4 / 20 / 66$ & $\begin{array}{l}\text { Observation } \\
\text { Recorder }\end{array}$ & $\begin{array}{l}\text { Cuttings collected-Elec. } \\
\text { tric ond gomme-rey } \\
\text { logs GGS1264 }\end{array}$ \\
\hline $18 \mathrm{H37}$ & $\begin{array}{l}\text { Adel Plating } \\
\text { Production Co. }\end{array}$ & Bishop Drl.Co. & $\ldots .$. & $\ldots .$. & Bored & 90 & 10 & $\ldots .$. & $\ldots .$. & $\ldots .$. & & OW analysis 11/17/65 \\
\hline $18 \mathrm{H3}$ & $\begin{array}{l}\text { Mont.Phosp Co. } \\
\text { Hole no.26 }\end{array}$ & Creasy Drl Co. & 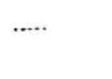 & 236.0 & Drilled & $185^{\circ}$ & 4 & .... & & $\cdots \cdot$ & & $\begin{array}{l}\text { Curtings collected-filled } \\
\text { in GGS1589 }\end{array}$ \\
\hline $18 \mathrm{H9}$ & W.S. Fletcher & do & $3 / . . / 66$ & 260.8 & do & 300 & 4 & 202 & 18185 & $4 / 20 / 66$ & $\begin{array}{l}\text { Domestic \& } \\
\text { Stock }\end{array}$ & $\begin{array}{l}\text { Cuttings collected } \\
\text { GGS1591 }\end{array}$ \\
\hline
\end{tabular}




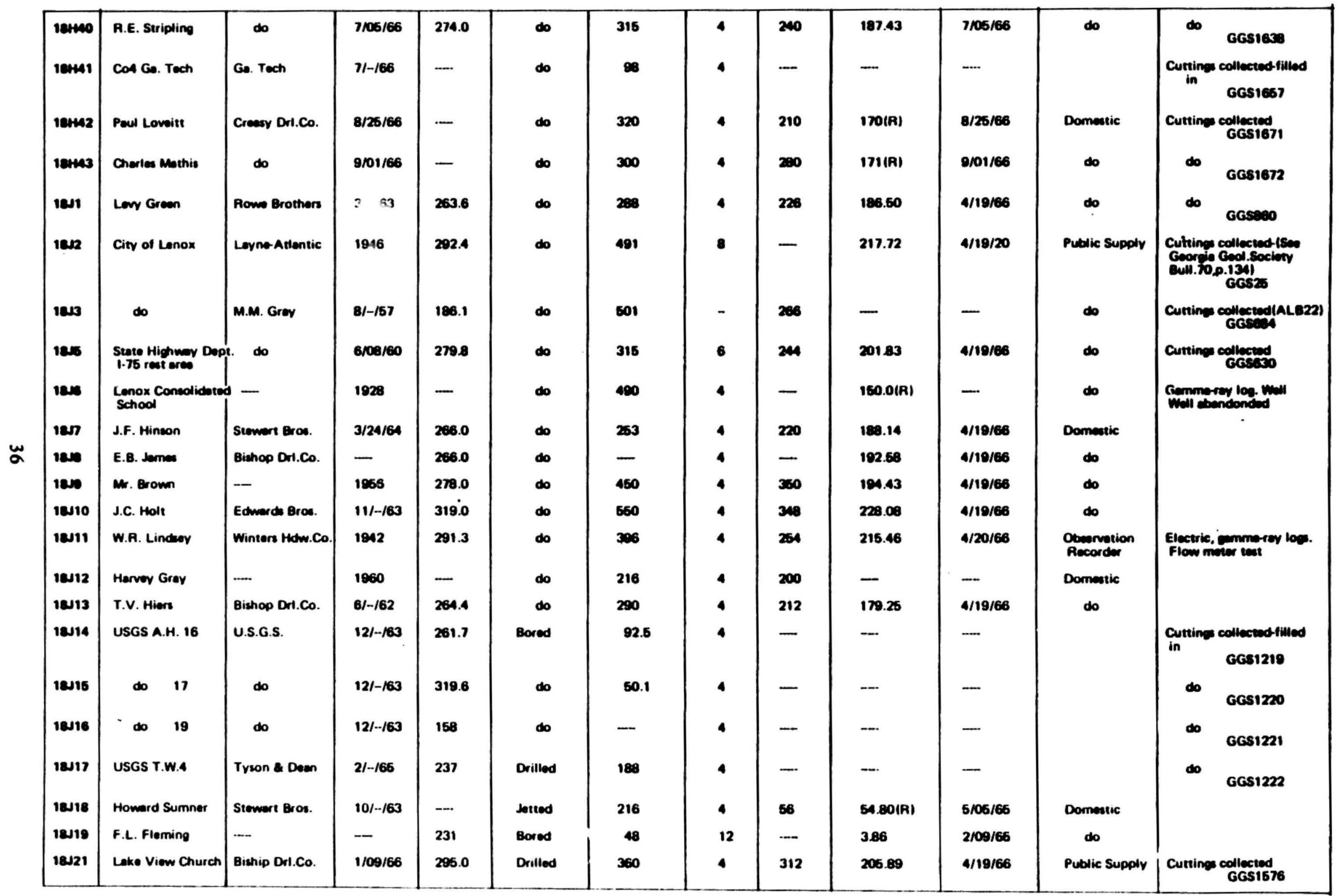




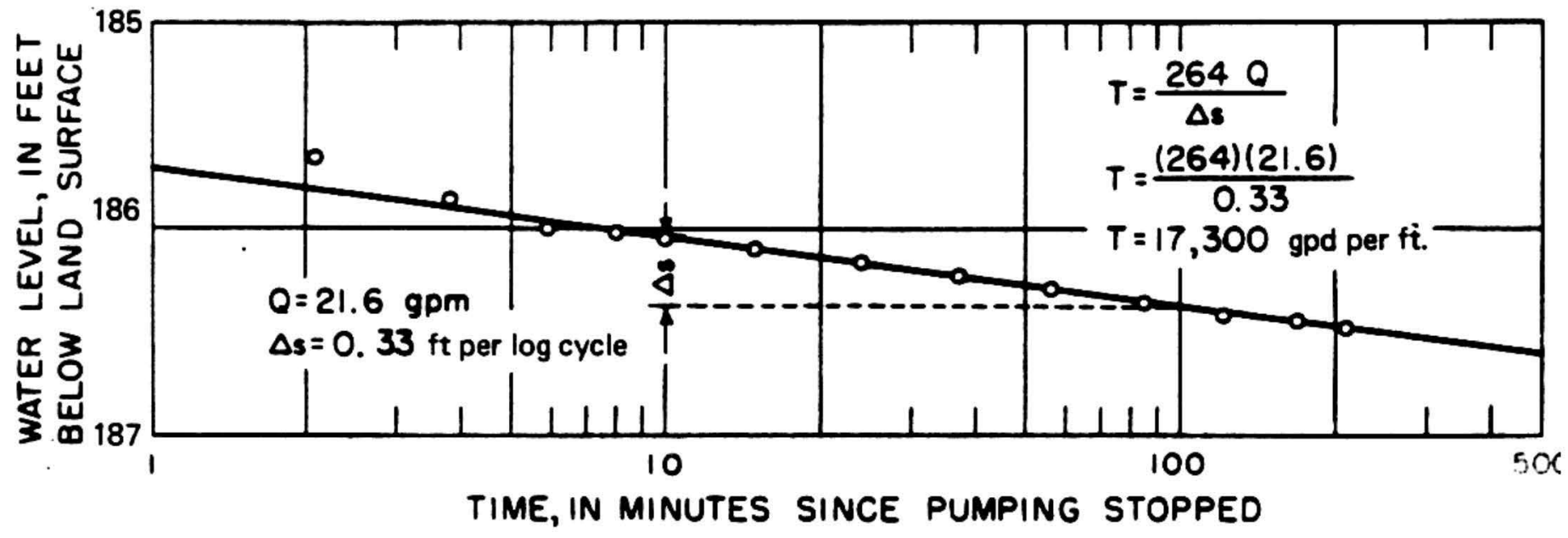

Figure 13. - Data plot for aquifer test in Tampa Formation at Laconte. 


\section{OTHER MINERAL RESOURCES}

Deposits of fuller's earth clay, phosphate, and sand are present within the county.

Nearly pure clay similar to fuller's earth was found in the Miocene deposits above the Tampa Formation over most of northern and western Cook County. The clay occurs in an 8- to 10-foot thick layer at a depth of 70 to 80 feet below land surface (about altitude 200 feet). X-ray diffractograms made by Dr. Ray Germillion (written commun., December $31,1963)$ show that sepiolite and attapulgite are the principal clay minerals. Montmorillonite also is present. Sever (1964, p. 17) shows the bulk density to be about 30.4 pounds per cubic foot and the oil retention to be 90.1 percent.

Five surface samples of clay were submitted to research laboratories to be tested for use in making ceramic products such as brick, tile, and similar items. These clays proved to be unsuitable for use as the primary body component in such products because of high vitrification temperatures, poor color, and very high shrinkage. The detailed laboratory reports are available for inspection at the Georgia Department of Natural Resources, Earth and Water Division, Room 400, 19 Hunter Street, S.W., Atlanta, Georgia.

Numerous white polished pellets of phosphate were observed near the base of the Hawthorn Formation in cuttings from auger holes drilled in southern Cook County. This zone is about 5 to 10 feet thick and generally contains less than 10 percent phosphate pellets. Gamma-radiation logs were made of 62 dug and bored wells in an effort to delineate the deposit. Figure 12 shows the area in Cook County thought to be underlain by this deposit. Chemical analyses of the phosphate are not available.

Sand deposits as much as 30 feet thick occur adjacent to Little River in western and southern Cook County. Those in western Cook County are being mined. A hole was augered through the terrace sands on the east bank of Little River on the north side of Georgia Highway 37 and samples of the sand were collected for sieve analysis. The results are shown in table 6.

Table 6. - Sieve analyses of sand from flood plain of Little River, western Cook County, Ga.

\begin{tabular}{|c|r|c|c|c|c|c|}
\hline $\begin{array}{c}\text { Siove } \\
\text { Opening } \\
\text { Size }\end{array}$ & \multicolumn{6}{|c|}{ Accumulative porcont rotsined } \\
\hline & 1.5 & $5 \cdot 10$ & $10 \cdot 15$ & $15 \cdot 20$ & $20 \cdot 25$ & $25 \cdot 30$ \\
\cline { 2 - 7 } 4 & 0.0 & 0.0 & 0.0 & 0.1 & 0.0 & 0.0 \\
8 & .0 & .0 & .0 & 1.7 & .0 & .0 \\
16 & .1 & .1 & .1 & 3.4 & 1.4 & 3.1 \\
30 & 1.7 & 8.9 & 13.9 & 17.5 & 18.3 & 20.6 \\
50 & 6.2 & 52.6 & 65.0 & 73.5 & 65.3 & 71.4 \\
70 & 19.4 & 76.1 & 84.2 & 92.8 & 81.7 & 87.4 \\
100 & 46.3 & 87.4 & 91.2 & 96.9 & 89.1 & 93.1 \\
140 & 76.6 & 94.5 & 95.4 & 99.0 & 95.1 & 98.9 \\
200 & 92.5 & 98.0 & 98.4 & 99.7 & 98.3 & 99.6 \\
Pan & 100.0 & 100.0 & 100.0 & 100.0 & 100.0 & 100.0 \\
\hline
\end{tabular}

The old terrace deposits adjacent to Little River in southern Cook County contain up to 0.5 percent heavy minerals, but the mineral concentrations appear to be too low grade and too scattered to be minable. However, these heavy minerals might be developed as a byproduct from sand mining. 


\section{SUMMARY AND CONCLUSIONS}

The limestones beneath Adel and most of Cook County contain drinkable water to a depth of only about 400 to 500 feet. Wells that tap these limestones obtain most of their water from a few thin, highly permeable zones rather than from the entire rock thickness.

The Ocala Limestone at Adel and probably throughout all of Cook County contains water of quality unsuitable for drinking. Wells should not be drilled deep enough to tap this aquifer.

Most “deep wells" tap the Suwannee and Marianna Limestones which are capable of yielding as much as $2,000 \mathrm{gpm}$ to wells. They contain water that is hard but which is suitable for municipal, irrigation, and most industrial uses. In northern Cook County many "semi-deep" wells tap the Tampa Formation which is capable of yielding only about 20 to $150 \mathrm{gpm}$ to wells. At places, wells which tap the Tampa yield a mixture of fine sand and water. The water, hough hard, is otherwise of quality suitable for domestic use. The yield of "shallow wells" is variable and the water generally is corrosive and at places contains appreciable dissolved iron.

The volume of ground water flowing through the Suwannee and Marianna Limestones in Cook County and available for development to properly spaced wells and well fields is estimated to be about $18,000 \mathrm{gpd}$. That in the Tampa is estimated to be about $1,500,000$ gpd.

The water level in wells at the Adel Third Street well field has declined 38 feet since 1890. It is presently declining at a rate of about 1.6 feet per year.

\section{REFERENCES}

Cooke, C. W., 1943, Geology of the Coastal Plain of Georgia: U.S. Geol. Survey Bull. 941, $117 \mathrm{p}$.

Cooper, H. H., Jr., and Jacob, C. E., 1946, A generalized graphical method of evaluating constants and summarizing well field history: Am. Geophys. Union Trans., v. 27, no. 4 , p. 526-534.

Ferris, J. G., Knowles, D. B., Brown, R. H., and Stallman, R. W., 1962, Theory of aquifer tests: U.S. Geol. Survey Water-Supply Paper 1536-E.

Herrick, S. M., 1961, Well logs of the Coastal Plain of Georgia: Georgia Geol. Survey Bull. 70,462 p.

Herrick, S. M., and Vorhis, R. C., 1963, Subsurface geology of the Georgia Coastal Plain: Georgia Geol. Survey Inf. Circ. 25, 67 p., 28 fig.

Jacob, C. E., 1950, Flow of ground water in Engineering hydraulics: John Wiley and Sons, New York, p. 321-386.

MacNeil, F. S., 1947, Geologic map of the Tertiary and Quaternary formations of Georgia: U.S. Geol. Survey Oil and Gas Inv. Prelim. map 72.

McCallie, S. W., 1898, A preliminary report on the artesian well system of Georgia: Georgia Geol. Survey Bull. 7, 209 p. Geol. Survey Bull. 15,360 p.

Sever, C. W., 1964, Fuller's earth clay found in Cook County, Georgia (abs.): Georgia Acad. Sci. Bull., v. 22, no. 2, p. 71.

1966, Reconnaissance of the ground water and geology of Thomas County, Georgia: Georgia Geol. Survey Inf. Circ. 34, 14 p.

Stephenson, L. W., and Veatch, J. O., 1915, Underground waters of the Coastal Plain of Georgia: U.S. Geol. Survey Water-Supply Paper 341, 539 p.

Theis, C. V., 1935, The relation between the lowering of the piezometric surface and the rate and duration of discharge of a well using ground-water storage: Am. Geophys. Union Trans., v. 16 , p. $519-524$.

Wait, R. L., 1960, Source and quality of ground water in southwestem Georgia: Georgia Geol. Survey Inf. Circ. 18, p. 43.

U. S. Public Health Service, 1962, Drinking water standards: Public Health Service Pub. No. 956. 